\title{
Determining the Errors of Primary School 5th Grade Students in Non-Routine Problem Solving*
}

\author{
Mustafa ULU $^{* *} \quad$ Neșe TERTEMIZ ${ }^{* * *} \quad$ Murat PEKER $^{* * * *}$
}

Received: 07 May 2015

Accepted: 15 December 2015

\begin{abstract}
The aim of this study is to determine the errors of 5th grade students in non-routine problems. In this study, descriptive survey method was used and clinical interview method was used in order to determine the source of the errors of $5^{\text {th }}$ grade students in non-routine problems. The study group of descriptive survey model was composed of 467 primary school $5^{\text {th }}$ grade students in 13 classes in 7 different primary schools in the city of Kütahya chosen according to cluster sampling method, while the study group of clinical interview method was composed of 70 students chosen among those who had made the error themes determined. As a result of the research, it was determined that the students made mostly comprehension-related errors (45.50\%); this comprehension based errors mostly resulted from miscomprehension (27.28\%), followed by irrelevant operation (10.42\%) and incomplete comprehension (7.39\%). It was also determined that the errors stemmed from the following: performing the strategy (5.72\%), reading (3.77\%), performing the operation (2.62\%) and choosing the right strategy (2.36\%), respectively.
\end{abstract}

Keywords: Mathematics, $5^{\text {th }}$ grade students, non-routine problem, mistake types, sources of the errors

\section{Extended Abstract}

Purpose and Significance: This study deals with mistakes in non-routine problems due to the facts that they require high level thinking skills, that more mistakes are seen both in student solutions and in teacher solutions and that the rate of utilization by teachers is low. During problem solving process, an individual is supposed to make sense of the problem during and after reading because without making sense of the problem, it is thought that individuals will come up with meaningless conclusions by using the numbers in the problem randomly. Problem solving skill is a complex process requiring use of information, and in this process students firstly need language skills. Because no studies have been encountered in Turkey about the relation between language skills and problem solving strategies, it is aimed in the study to determine the source of the mistakes of primary school students in non-routine problems. In this context, answers for the following questions are sought:

1. How is the distribution of the mistakes of primary school 5th grade students in non-routine problems according to mistake types?

\footnotetext{
* This paper is a part of corresponding author's unpublished doctoral dissertation.

${ }^{* *}$ Corresponding Author: Assist. Prof. Dr., Dumlupınar University, Kütahya, Turkey, mustafa.ulu@dpu.edu.tr

****Assoc. Prof. Dr., Gazi University, Ankara, Turkey, tertemiz@gazi.edu.tr

***** Prof.Dr., Afyon Kocatepe University, Afyonkarahisar, Turkey, peker@aku.edu.tr
}

\section{Citation Information}

Ulu, M., Tertemiz, N., \& Peker, M. (2016). İlköğretim 5. sınıf öğrencilerinin problem çözme sürecinde yaptıkları hata türlerinin belirlenmesi.Kuramsal Eğitimbilim Dergisi [Journal of Theoretical Educational Science], 9(4), 571605. 
2. What are the reasons for primary school 5th grade students to make mistakes in non-routine problems?

Methods: In the research, descriptive survey and clinical interview methods were used together. Survey models are research approaches that aim to describe a former or an existing case as it is. In this context, because the answer for the first question of the research "How is the distribution of the mistakes of primary school 5th grade students in non-routine problems according to mistake types?” hadn't been intervened, the answer was sought through descriptive survey method. As one of the measuring methods that could be used in evaluating problem solving skill, clinical interview method is a method in which the reason for the mistakes students make while solving a problem is revealed by observing the student during problem solving. Based on this, clinical interview method was used for the second question of the research "What are the reasons for primary school 5th grade students to make mistakes in non-routine problems?” both to reveal the causes of the mistakes and misperceptions of the students and for students themselves to determine their own mistakes.

The population of the research consists of the 5th grade students at 34 state primary schools in the city centre of Kütahya during 2010/2011. Because it was very difficult to reach the whole population, it was decided to form a study group by using proportional cluster sampling method.

In the study, success test for non-routine problem solving (ROPÇBT) composed of 12 questions whose reliability and validity studies were conducted by Ulu (2011) was used to determine the mistakes of primary school students in non-routine problems.

In order to determine why students make mistakes in non-routine problems, the converted form of problem solving mistake analysis inventory developed by Newman (1977) into clinical interview from by White (2005) was used.

ROPÇBT was conducted in a sample of 467 primary school 5th grade students at 13 classes, and its administration took 45 minutes. Data analysis was conducted using percentage and frequency values.

Findings and Discussion: As a result of the study, it was seen that about 75\% (59.97\% false $+14.96 \%$ empty) of the mistakes in non-routine problems resulted in failure. The finding that the mistakes in non-routine problems is coherent with the finding in the studies by Verschaffel, DeCorte, and Lasure (1994), Verschaffel and DeCorte (1993), Verschaffel, DeCorte, and Vierstraet (1999), Jurdak (2006), Xin, Lin, Zhang and Yan (2007).

The analysis of the mistake sources in the study shows that about half of the solutions (49.26\%) involve mistakes arising from comprehension-based mistakes. The findings of the research that students mostly made comprehension-based mistakes are coherent with the findings in the studies by Singh, Rahman, Hoon, (2010), Clements and Ellerton (1996), Marinas and Clements (1990), Clarkson (1991). The fact in the study that 
comprehension-related mistakes are too many in number shows the necessity that activities for what is read in problem solving practices should be increased and reading comprehension strategies should be adapted to problem solving practices.

In the study, comprehension-based mistakes were categorized in three different ways as irrelevant operations, inaccurate uncompleted and accurate incomplete solutions. It was determined that although the rate of irrelevant operation-based mistakes was $10.42 \%$ and the operations chosen by the students who made these mistakes were not even remotely closed to the solution, they nevertheless conducted the operations accurately. The fact that similar results were obtained in the studies by Kroll and Miller (1993), Tertemiz (1994), and Prakitipong and Nakamura (2006) lets us see that the mistakes in four-operation problems are more comprehension-based than stemming from basic mathematical skills.

It is also seen in the study that other comprehension-based mistakes stem from conversion of the oral expressions in the problem into visual and mathematical expressions (inaccurate incomplete solutions $=27.28 \%$ ) inaccurately or deficiently (accurate incomplete solutions $=7.79 \%$ ). It was found in the studies by Panasuk and Beyranevand (2010), Moreno and Mayer (1999), Hegarty, Mayer and Monk (1995) that students who could use multiple conversion techniques (symbolic, visual, oral) in comprehending the problem were more successful. The fact that conversion-based mistakes were too many in the study shows the necessity that multiple conversion techniques should be used in problem solving practices.

The proportion of problem solving strategy knowledge-based mistakes (strategy choice and strategy execution-based) to the overall rate of the test is $8.08 \%$ (453). The first of the problem-solving strategy knowledge-based mistakes stems from the mistakes arising from strategy choice and the proportion of these mistakes to the overall is $2.36 \%$. Schonfeld (2005) suggests that in order to choose a suitable strategy, students should be exposed to such different types of problems as possible. In a study by Koedinger and Tabahneck (1994), it was seen that compared with those who hadn't made the right strategy choice initially and insisted on the same inaccurate strategy, those who changed strategy when they reached a deadlock and re-made the solution were more successful. In a study by Ulu (2008), it was determined that primary school students mostly use mathematical sentence writing strategy, as similar to the findings of this study.

The second of the problem-solving strategy knowledge-based mistakes are the ones arising from strategy execution and their proportion to the overall is $5.72 \%$. In the study, it was seen that these mistakes stemmed from inaccurate drawing of the figure or inaccurate interpretation of an accurate drawing. This finding is coherent with those in the studies by Hong (1993, 1995) and Pantziara, Gagatsis, and Elia (2009).

As a result of the study, the fact that some students chose inaccurate strategy and always used the same strategy (strategy of writing mathematical sentence) and that some students couldn't execute their chosen strategy reveal the necessity of the focus on the training of problem solving strategy. Because it was seen in the studies by Altun et al. 
(2004), Sulak (2005), Yazgan and Bintaş (2005), Altun and Arslan (2006) and Yavuz (2006), the training of problem solving strategy could increase problem solving success. It was observed in the research that the proportion of operation-based mistakes to overall is 2.62\%. It was seen in studies by Teong (2000) and Özsoy (2007) that using control processes could decrease operation-based mistakes. 


\title{
İlköğretim 5. Sınıf Öğrencilerinin Problem Çözme Sürecinde Yaptıkları Hata Türlerinin Belirlenmesi*
}

\author{
Mustafa ULU $^{* *} \quad$ Neșe TERTEMIZ $^{* * *} \quad$ Murat PEKER $^{* * * *}$
}

Makale Gönderme Tarihi: 07 May1s 2015

Makale Kabul Tarihi: 15 Aralık 2015

\begin{abstract}
ÖZ: Bu araştırmanın amacı ilköğretim 5.sınıf öğrencilerinin problem çözme sürecinde yaptıkları hata türlerinin belirlenmesidir. İlköğretim 5. sınıf öğrencilerinin rutin olmayan problemlerde yaptıkları hataların kaynağını belirlemek amaciyla betimsel tarama ve klinik mülakat metodundan faydalanılmıştır. Betimsel tarama modelinin çalışma grubunu küme örnekleme yöntemiyle seçilmiş Kütahya ili yedi farklı ilköğretim okulunun 13 şubesinde eğitim gören toplam 467 İlköğretim 5. sınıf öğrencisi oluşturmaktadır. Klinik mülakat yönteminin çalışma grubunu belirlenen hata temalarını yapan öğrenciler arasından seçilen 70 öğrenci oluşturmaktadır. Araştırma sonucunda öğrencilerin en fazla anlama kaynaklı (\%45.50) hata yaptıkları; anlama kaynaklı hataların en fazla yanlış anlama kaynaklı (\%27.28) olduğu, yanlış anlama kaynaklı hataları ilgisiz işlem (\%10.42) kaynaklı ve eksik anlama (\%7.39) kaynaklı hataların takip ettiği görülmüştür. Anlama kaynaklı hataların haricinde yapılan hataların sırasıyla yanlış stratejinin yürütülmesi (\%5.72), eksik ya da yanlış okuma (\%3.77), yanlış hesaplama yapılması (\%2.62) ve hatalı strateji seçiminden (\%2.36) kaynaklandığı belirlenmiştir.
\end{abstract}

Anahtar kelimeler: Matematik, 5.sınıf, rutin olmayan problem, hata türleri, hata kaynakları

\section{Giriş}

Problem çözme becerisinin matematik programlarına girmesiyle birlikte, öğrencilerin problem çözerken yaptıkları hataların nedenlerini belirlemek amacıyla ilk olarak Newman (1977) tarafından "problem çözme hata analizi envanteri" geliştirilmiş; ilköğretim öğrencilerinin problem çözerken yaptıkları hataların nedenleri okuma, anlama, dönüştürme, hesaplama, sonuç yazma, motivasyon, dikkatsizlik, problem metni olmak üzere sekiz başlık altında incelenmiştir. Daha sonra Hong (1993) tarafindan geliştirilen envanterde hatalar "sayı işlem modeli, sayı deneme modeli, mental yetersizlik, şemanın yanlış yapılandırılması, yanlış ilişkilendirme ve dikkatsizlik" olmak üzere altı başlık altında incelenmiştir. Yeo (2009) tarafindan geliştirilen hata analiz envanterinde "okuma, anlama, strateji seçimi, stratejinin yürütülmesi, hesaplamanın yapılması" olmak üzere beş başlık altında incelenmiştir. Fong (1995) ise problem çözerken yapılan hata türlerini dilsel, dönüştürme, matematiksel ve psikolojik faktörler olmak üzere dört ana başlık altında toplamıştır.

Dil kaynaklı hatalar Yeo (2009) ve Newman (1977) tarafindan yapılan çalı̧̧malarda okuma ve anlama şeklinde verilmiş; Fong (1995) ise anlama kaynaklı hataları ilgisiz işlemler, yanlış anlama ve eksik anlama şeklinde kategorize etmiştir. Dönüştürme kaynaklı hatalar Steele ve Johanning (2004), Pape ve Tchoshanov (2001), Healy ve Hoyles (1999) tarafindan yapılan çalışmalarda içsel ve dışsal olmak üzere ikiye ayrılmıştır. İçsel dönüştürmeden kaynaklanan hataların geri getirme (Passolunghi \& Pazzaglia, 2004/2005; Teong, 2002), ilişkilendirme (Marshall, 1995; Hong, 1993/1995; Koedinger \& Tabahneck, 1994), planlama ve planın uygulanmasından

\footnotetext{
*Bu çalışma sorumlu yazarın yayınlanmamış doktora tezinin bir parçasıdır.

*** Sorumlu Yazar: Yrd. Doç. Dr., Dumlupınar Üniversitesi, Kütahya, Türkiye, $\underline{\text { mustafa.ulu@dpu.edu.tr }}$

${ }^{* * * *}$ Doç. Dr., Gazi Üniversitesi, Ankara, Türkiye, tertemiz@gazi.edu.tr

***** Prof.Dr., Afyon Kocatepe Üniversitesi, Afyonkarahisar, Türkiye, peker@aku.edu.tr
} 
(Baddeley \& Logie 1999; Charles \& Lester, 1984; Teong, 2002; Wu \& King, 2011) kaynaklandığı belirtilmiştir. Problem metninin kelime, şekil ve sembollere yanlış dönüştürülmesi (Duval 2002; Healy \& Hoyles, 1999; Hong, 1993/1995; Moreno \& Mayer, 1999; Pape \& Tchoshanov 2001) dışsal dönüştürme hataları olarak ifade edilmiştir. Matematiksel hataların temel becerilerdeki (Anderson, 2008/2010; Jordan, Hanich, \& Kaplan, 2003; Hanich, Jordan, Kaplan, \& Dick, 2001; Kaur, 1997) ve öğrenme alanlarındaki (Grimm, 2008; Hallett, Nunes \& Bryant, 2010; Singh, Rahman ve Hoon, 2010) eksikliklerden kaynaklandığ1; psikoloji kaynaklı hataların ise dikkat ve motivasyon kaynaklı olabileceği (Fong, 1995; Hong 1993/1995; Newman, 1977) belirlenmiştir. Yapılan çalışmalardan hareketle ilköğretim öğrencilerinin problem çözerken yaptıkları hataların nedenleri şema haline getirilerek, Şekil 1'de verilmiştir.

Şekil 1. Problem Çözerken Yapılan Hataların Nedenleri

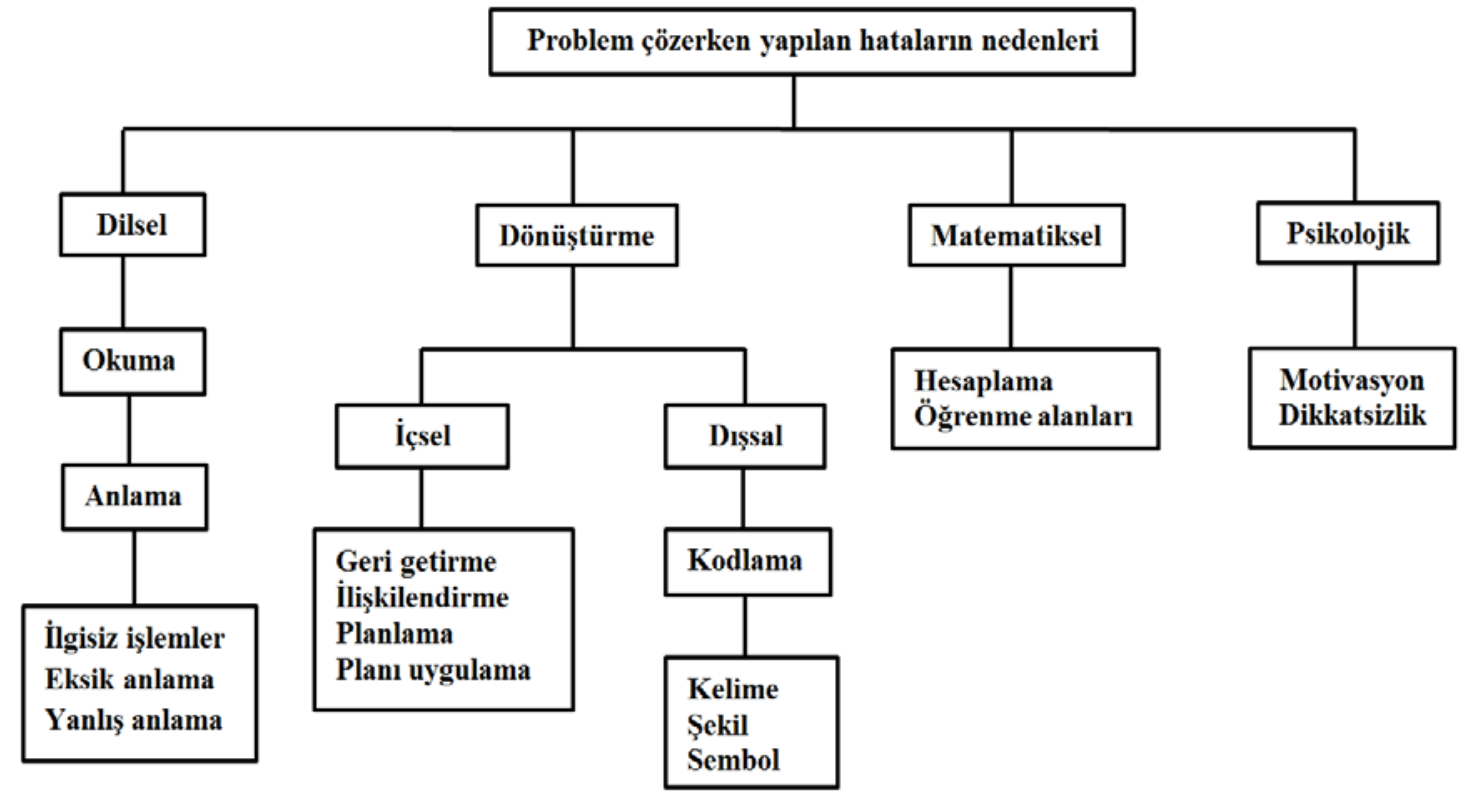

Şekil 1 incelendiğinde problem çözme becerisinin birçok bilginin bir arada kullanılmasını gerektiren karmaşık bir süreç olduğu; bu süreçte öğrencilerin öncelikle dil becerilerine ihtiyaç duydukları görülecektir (Artzt \& Thomas, 1992; Hong, 1993; Mayer, 1985; Polya, 1990). Bautista, Mitchelmore ve Mulligan (2009) tarafindan Filipinler'de yapılan bir çalışma, dil becerilerinin problem çözme başarısı üzerindeki etkisini görmemizi sağlamaktadır. Filipinler'deki öğrencilerin anadilleri Filipince olmasına rağmen eğitim dilleri İngilizcedir. Aynı öğrencilere aynı problemler İngilizce ve Filipince metinler halinde sorulmuş, çalışma sonucunda ilköğretim öğrencilerinin İngilizce metinlere oranla anadillerinde daha başarılı oldukları saptanmıştır.

Clarkson (1991), Clements (1982), Clements ve Ellerton (1996), Fong (1995), Hong (1993/1995), Marinas ve Clements (1990), Singh ve diğerleri (2010), Singhatat (1991) tarafindan yapılan çalışmalarda ilköğretim öğrencilerinin problem çözerken \%25 ile \%75 arasında değișen oranlarda dil kaynaklı hatalar yaptıkları bulgusuna; Chinn ve 
Ashcroft (1993), Grimm (2008), Light ve DeFries (1995), Pape, (2004), Tuohimaa, Aunola, Nurmi (2008) tarafından çalışmalarda ise ilköğretim öğrencilerinin problem çözme başarıları ile dil becerileri arasında yüksek ilişki olduğu (.47 ile .76 değişen oranlarda) bulgusuna ulaşılmıştır.

Şekil 1'den de anlaşılacağı gibi problem çözme sürecinde dil becerileri okuma ve anlama olmak üzere iki kategoride incelenmektedir; fakat Akyol (2006) okumanın anlamadan bağımsız olmadığını düşünmekte, metnin çeşidi ne olursa olsun okumadaki amacın anlam kurma olduğunu savunmaktadır. Ona göre bireyler metni anlamak için akıcı okuma (metnin amacına uygun hız belirleme ve doğru okuma) becerisine sahip olmalı; analiz edici metinleri (problem metinleri) diğer metin türlerine oranla daha yavaş ve doğru okumalıdırlar. Tuohimaa ve diğerleri (2008) tarafından yapılan çalışma Akyol (2006)'un görüşlerini doğrular niteliktedir. İlköğretim dördüncü sınıf öğrencileri üzerinde yapılan çalışmada; öğrencilerin akıcı okuma (hız, doğruluk, kelime ilişkilendirme), anlama (neden sonuç ilişkisi, çıkarımda bulunma, ana fikir bulma, deyimler bilgisi) ve problem çözme becerileri arasındaki ilişki incelenmiştir. Çalışma sonucunda akıcı okuma becerisinin anlama becerisini doğrudan, problem çözme becerisini anlama becerisi aracılığıyla yordadığı; okuduğunu anlama becerisi ile problem çözme becerisi arasında yüksek $(r=.67)$ ilişki olmasına rağmen, akıcı okuma puanları kontrol edildiğinde anlama becerisi ile problem çözme becerisi arasındaki ilişkinin düştüğü ( $r=.47)$ bulgusuna ulaşılmıştır. Bu durum akıcı okumanın anlama ve problem çözme başarısı üzerindeki etkisini görmemizi sağlamaktadır.

Problem çözme sürecinde okuma esnasında ve sonrasında bireyin problem metnini anlamlandırması gerekmektedir; anlama olmadığı takdirde bireylerin problemde verilen sayıları tesadüfî bir şekilde kullanarak anlamsız sonuçlara ulaşacakları düşünülmektedir (Morales, 1998, Polya, 1990). Prakitipong ve Nakamura (2006) tarafından yapılan çalışmada iyi problem çözücülerin anlama seviyelerinin yüksek olduğu, fakat problem çözme başarısı yüksek öğrenciler ile problem çözme başarısı düşük bireyler arasında matematiğin temel becerilerine sahip olma konusunda büyük farklılıkların olmadığı görülmüştür. Kroll ve Miller (1993) tarafından ilköğretim öğrencileri üzerinde yapılan bir çalışmada sorular öncelikle dört işlem halinde daha sonra aynı sorular problem metnine dönüştürülerek sorulmuş; çalışma sonucunda bazı öğrencilerin dört işlemi yapabilirken, problemleri yapamadıkları saptanmıştır. Tertemiz (1994) tarafından yapılan çalışmada problem çözme becerileri orta ve üst düzeyde olan öğrencilerin dört işlem becerisinin yanı sıra problemi anlama düzeylerinin de yüksek olduğu, bu durumun aksine düşük başarı gösteren öğrencilerin sadece dört işlem becerilerinin yeterli olduğu bulgusuna ulaşılmıştır. Ulu (2011) ve Hite (2009) tarafından yapılan çalışmalar ise sadece okuduğunu anlama eğitimi verilerek ilköğretim öğrencilerinin problem çözme başarılarının bir miktar artırılabildiğini göstermektedir.

Anderson (2010), Grimm (2008), Jordan, Kaplan ve Hanich (2002) tarafindan yapılan boylamsal çalışmalarda okuduğunu anlama becerilerinin yıllar geçtikçe problem çözme başarısı üzerindeki etkisini artırdığı görülmüştür. Jordan ve diğerleri (2002) tarafından yapılan çalışmada sadece anlama güçlüğü (AG), sadece matematik güçlüğü 
(MG) yaşayan öğrencilerle, normal gelişim (NG) gösteren öğrencilerin ikinci sınıfın başından üçüncü sınıfın sonuna kadar problem çözme başarılarındaki gelişim gözlemlenmiştir. Çalışma sonucunda ikinci sınıfın başında AG yaşayan öğrencilerin problem çözme başarılarının NG gösteren öğrencilerle aynı ve MG yaşayan öğrencilerden yüksek olmasına rağmen; üçüncü sınıfin sonunda $M G$ yaşayan öğrencilerle aynı seviyeye geldiği, NG gösteren öğrencilere oranla gerilediği gözlemlenmiştir. Anderson (2010) MG ve AG yaşayan öğrencileri ve NG gösteren öğrencileri problem çözme becerisi açısından dördüncü sınıfın başından beşinci sınıfın sonuna kadar gözlemlemiş; çalışma sonucunda NG gösteren öğrencilerle AG ve MG yaşayan öğrenciler arasındaki farkın artarak devam ettiğini saptamıştır. Bu duruma gerekçe olarak sınıf seviyesine paralel olarak hem problemlerin zorlaşması hem de okuduğunu anlamaya olan gereksinimin artması gösterilmiştir. Grimm (2008) tarafindan yapılan çalışmada öğrencilerin üçüncü sınıfın başından sekizinci sınıfın sonuna kadar zihinden hesaplama, tahmin, kâğıt üzerinde hesaplama, problem çözme, okuduğunu anlama ve matematiğin öğrenme alanlarındaki (sayılar, geometri, veri, olasılık) gelişimleri incelenmiştir. Çalışma sonucunda üçüncü sınıfta kazanılan okuduğunu anlama becerilerinin sekizinci sınıfın sonuna kadar sırasıyla en fazla problem çözme başarısındaki gelişimi yordadığı; problem çözme başarısını öğrenme alanları ve hesaplama becerilerindeki gelişimin takip ettiği görülmüştür. Bu çalışmalar okuduğunu anlama becerilerinin erken yaşlarda geliştirilmesinin gerekliliğini ortaya koymaktadır.

Şekil 1 incelendiğinde anlama basamağını dönüştürme basamağının takip ettiği görülecektir. Clarkson (1991), Clements (1982), Clements ve Ellerton (1996), Fong (1995), Hong (1993/1995), Marinas ve Clements (1990), Singh ve diğerleri (2010), Singhatat (1991) tarafından yapılan çalışmalarda ilköğretim öğrencilerinin \%7 ile \%40 arasında değişen oranlarda dönüştürme kaynaklı hata yaptıkları bulgusuna ulaşılmıştır. Diğer taraftan Healy ve Hoyles (1999), Pape ve Tchoshanov (2001), Steele ve Johanning (2004) tarafından yapılan çalışmalarda dönüştürme basamağının anlam kurma sürecinden bağımsız olmadığı belirlenmiş; bu duruma paralel olarak problemi anlama "verilen problem metninin aslının bozulmadan önce içsel, daha sonra dışsal ifadelere dönüş̧ürülmesi” ş̧eklinde tanımlanmıştır.

İçsel dönüştürmenin ilk basamağı geri getirme basamağı olup bu basamakta bireyden beklenen; çözeceği problemle ilgili uzun süreli belleğinde var olan bilgileri seçerek kısa süreli belleğine aktarmasıdır. Charles ve Lester (1984) ile Altun (2007) ise bireylerin çözüm öncesinde "Daha önce buna benzer problem çözdüm mü?” sorusunu kendilerine sormalarını, benzer problemlerde kullandıkları çözüm yöntemlerini mevcut problem durumuna uyarlama amaçlı geri getirmelerini istemektedir. Baki ve Kartal (2004) ise geri getirmenin problem çözmeye yeni başlayan öğrenciler için çok daha önemli olduğunu, çünkü bu öğrencilerin tecrübeli çözücüler olmadıkları için sık sık daha önce çözdüğ̈̈ problemlerden yararlandıklarını vurgulamaktadır. Bu nedenle geri getirme hem bilişsel hem de stratejik bağlamda problem çözme sürecinin önemli bir parçası olarak görülebilir. 
İçsel dönüştürmenin ikinci basamağı ilişkilendirme olup bu basamakta bireyden beklenen; problemin çözümü için uzun süreli belleğinden geri getirdiği bilgileri organize etmesi, problemde verilenleri istenilenler doğrultusunda ayırt etmesi ve mevcut problem durumuna uyarlamasıdır (Cummins, Kintsch, Reusser \& Weimer, 1988; Steele \& Johanning, 2004). Passolunghi ve Pazzaglia (2004/2005) yapılan çalışmalarda problem çözme başarısı yüksek öğrenciler ile problem çözme başarısı düşük bireyler arasındaki farkın geri getirmeden çok ilişkilendirmeden kaynaklandığı bulgusuna ulaşılmıştır. Çalışmada kullanılan "Haftada yedi gün vardır. John haftada $12 \mathrm{~km}$ yürümektedir. John bir ayda kaç kilometre yürür?” problem cümlesinde çözüm için "haftada yedi gün vardır" ifadesi gereksizdir. Öğrencilerden beklenen " $12 x 4=48$ " sonucuna ulaşmalarıdır. Ancak, öğrenciler gereksiz bilgiyi ayırt edemedikleri için “12x7=84” sonucuna ulaşmışlardır. İlişkilendirme kaynaklı hatalara Viennot ve Moreau (2007), Hong (1993/1995) tarafından yapılan çalışmalarda da rastlanmıştır.

Geri getirme ve ilişkilendirme süreçlerini halleden bireyden içsel dönüşümü sağlayabilmesi için sonraki aşamada problemin çözümünü zihninde planlaması ve bu planı harekete geçirmesi beklenmektedir. Planlama süreci çözüm için strateji seçimi; planın uygulanması süreci ise seçilen stratejinin yürütülmesi ve seçilen strateji sonuca ulaştırmıyorsa stratejinin değiştirilmesi olarak ifade edilmektedir (Altun, 2005; Schoenfeld, 2005). Altun, Bintaş, Yazgan ve Arslan (2004), Altun ve Arslan (2006), Sulak (2005), Yazgan ve Bintaş (2005), ve Yavuz (2006) tarafindan yapılan araştırmalarda problem çözme strateji eğitiminin problem çözme başarısını artırdı̆̆ 1 görülmüştür. Problem çözme becerileri düşük öğrencilerin çözüm esnasında sürenin büyük kısmını tekrarlı okumalara (Teong, 2002) veya problemin amacina uygun olmayan hesaplamalara (Hegarty, Mayer, \& Green, 1992) ayırdıkları tespit edilmiş; aynı çalışmalarda problem çözme becerileri yüksek öğrencilerin çözüm esnasında anlamlandırma ve planlamaya ağırlık verdikleri görülmüştür. Diğer taraftan Teong (2002) tarafından yapılan çalışmada 10-11 yaş öğrencilerine planlama eğitimi verilmiş, sürecin ilk aşamasında öğrencilerin plan yaparken zorlandıkları, planlama sürelerinin çok uzadığı ve yanlış cevapların arttığı görülmüş, eğitimin ilerleyen dönemlerinde ise sürenin kısaldığı ve doğru çözümlerin arttığı tespit edilmiştir. Çalışma sonucunda planlama eğitiminin öğrenci başarısını \%50 oranında artırdığı, kalıcılık testi sonuçları ise öğrencilerin plan yapmayı beceri haline getirebildiklerini ortaya koymuştur.

Gyamfi (1993) yaptığ1 çalışmada içsel dönüştürmenin ancak dışsal dönüştürme teknikleri kullanılarak somut ve gözlemlenebilir hale gelebileceğini ortaya koymuştur. Hegarty, Mayer ve Mog (1995) problemi dişsal dönüştürmede üç teknik olduğunu ileri sürmüşler, bu teknikleri kelime, sayı ve eylem odaklı olarak adlandırmışlardır. Kelime odaklı çözen öğrencilerin "fazlası, eksiği" gibi anahtar kelimelere odaklandığı veya sayıları anlamlandırmadan işlem yaptıkları belirlenmiştir. Soylu ve Soylu (2006) tarafından yapılan bir çalışmadan alınan örnek ise aslında anahtar kelimelerin öğrenciyi nasıl yanlışa yönlendirdiğini göstermektedir. "Ali elmalarından 5 tanesini Ayşe'ye verince geriye 10 elması kalmıştır. Buna göre Ali'nin başlangıçta kaç elması vardı?", sorusuna öğrencinin verdiği cevap $10-5=5$ olmuştur. Yapılan mülakat sonucunda 
"geriye ......kald $\imath "$ ifadesi öğrenciyi toplama işlemi yerine çıkarma işlemi yapmaya teşvik etmiştir. Hegarty ve diğerleri (1995) tarafindan yapılan çalışmada ayrıca kelime odaklı anlamlandırma yapan öğrencilerin göz hareketlerinin sayılar üzerine odaklandığ 1 belirlenmiştir. DeCorte ve Verschaffel (2002) tarafindan yapılan çalışmada anlamlandırma olmaksızın yapılan sayı odaklı çözümlerinde tıpkı anahtar kelimeler gibi öğrencileri alakasız çözümlere götürdüğü belirtilmiştir. Çalışmada "Bir gemide 26 koyun ve 10 keçi vardır. Geminin kaptanı kaç yaşındadır?" şeklindeki bir soruda öğrencilerin soruyu anlamadan toplama işlemi yaparak 36 sonucuna ulaştıkları tespit edilmiştir. Hegarty ve diğerleri (1995) eylem odaklı çözen öğrencilerin kelime ve sayı odaklı çözen öğrencilerden daha başarılı olduklarını ortaya koymuşlardır. Moreno ve Mayer (1999), eylem odaklı çözümleri "çoklu dönüştürme” (sembolik, görsel, sözel) şeklinde isimlendirmişler ve Hegarty ve diğerleri (1995) tarafından yapılan çalışmada elde edilen bulgulara benzer bulgular elde etmişlerdir. Panasuk ve Beyranevand (2010) aynı problem cümlesini sözel, görsel ve sembolik olmak üzere üç değişik formda sormuşlar, soruların aynı olduğunu düşünen öğrencilerin sözel formda verilen problemleri diğer formlara (görsel, sembolik) dönüştürmede zorlanmadıkları; her problemin faklı olduğunu düşünen öğrencilerin ise sözel formda verilen problemleri diğer formlara dönüştüremedikleri tespit edilmiştir. Çalışma sonucunda dönüşüm yapabilen öğrencilerin yapamayan öğrencilerden daha başarılı oldukları tespit edilmiştir.

Şekil 1'de belirtildiği gibi problem çözerken yapılan hataların bir diğer nedeninin matematiksel becerilerle (hesaplama, öğrenme alanları) ilgilidir. Anderson (2008), Anderson (2010), Hanich ve diğerleri (2001), Jordan ve diğerleri (2003), Kaur (1997) tarafından yapılan çalışmalarda anlama yönüyle normal gelişim gösteren fakat MG yaşayan öğrencilerin de tıpkı matematiksel işlemleri yapabilme yönüyle normal gelişim gösteren fakat AG yaşayan öğrenciler gibi problem çözmede başarısız oldukları görülmüştür. Matematiksel hataların ilki olan hesaplama hatalarına \%2 ile \%12 arasında değişen oranlarda rastlanmıştır (Clarkson, 1991; Clements, 1982; Clements ve Ellerton, 1996; Fong, 1995; Hong, 1993/1995; Marinas ve Clements, 1990; Singh ve diğerleri, 2010; Singhatat, 1991; Ulu, 2011). Matematiksel kaynaklı hataların bir diğeri ise öğrenme alanlarındaki (sayılar, geometri, veri, olasılık) eksikliklerden kaynaklanmaktadır. Hallett ve diğerleri (2010) tarafından yapılan bir çalışmada bazı öğrencilerin kesirleri dönüştürmeyi bilmedikleri için hata yaptıkları görülmüştür.

Şekil 1 incelendiğinde problem çözerken yapılan hataların nedenlerinden sonuncusu ise psikolojik (motivasyon, dikkat) nedenlerden kaynaklanan hatalardır. Psikoloji kaynaklı hatalara da \%2 ile \%28 arasında değişen oranlarda rastlanmıştır (Clarkson, 1991; Clements, 1982; Clements ve Ellerton, 1996; Fong, 1995; Hong, 1993/1995; Marinas ve Clements, 1990; Singh ve diğerleri, 2010; Singhatat, 1991). Bu çalışmalarda motivasyon ve dikkat kaynaklı hataların problem çözme sürecinin her aşamasında; bazen yanlış okuma, bazen yanlış anlama veya eksik anlama, bazen yanlış dönüştürme, bazen yanlış hesaplama şeklinde gerçekleştiği görülmüştür. Teong (2002) tarafından yapılan çalışmada motivasyon ve dikkat kaynaklı hataların özellikle çözüm 
hızıyla ilgili olduğu belirlenmiş, bazı öğrencilerin kendilerine aşırı güvendikleri için acele davrandıkları ve soruyu çözebilecekken hata yaptıkları gözlenmiştir. Çalışma sonucunda motivasyon ve dikkat kaynaklı hataların azaltılması için Polya (1990) tarafından önerilen problem çözme sürecinin son basamağ 1 olan geriye dönüş basamağının kullanılması önerilmiş, sağlama yapan öğrencilerin çoğunluğunun dikkat kaynaklı hataları azalttıkları görülmüştür. Özsoy (2007) tarafından çalışmada kontrol süreçlerinin hataları azalttığı belirlenmiştir.

Bu çalışmada gerek üst düzey düşünme becerilerini gerektirmesi (Altun, 2005, Baki ve Kartal 2004; Kaur ve Yeap, 2009; Teong, 2002; Polya,1990); gerek öğrenci çözümlerinde (Jurdak 2006; Xin, 2007; Ulu 2008; Verschaffel ve diğerleri, 1994; Verschaffel ve diğerleri 1999), gerek öğretmen çözümlerinde (Asman ve Markovits, 2009; Ulu, 2008) daha fazla hataya rastlanması ve gerekse öğretmenler tarafından kullanılma oranlarının düşük olması nedeniyle (Asman ve Markovits, 2009; Lee ve Kim, 2005) rutin olmayan problemlerde yapılan hatalar üzerinde durulmuştur.

Clarkson (1991), Clements (1982), Clements ve Ellerton (1996), Fong (1995), Hong (1993/1995), Marinas ve Clements (1990), Singh ve diğerleri (2010), Singhatat (1991) tarafından yapılan çalışmalarda rutin problemlerdeki hata kaynakları tespit edilmiştir. Jurdak (2006), Xin ve diğerleri (2007), Ulu (2008), Verschaffel ve diğerleri (1994), Verschaffel ve diğerleri (1999) tarafından yapılan çalışmalarda rutin olmayan problemlerde yapılan hata oranları araştırılmasına rağmen hataların kaynağı araştırılmamıştır. Rutin olmayan problemlerde yapılan hatalar üzerinde Fong (1995) tarafından yapılan çalışmada hataların kaynağı şematik modele göre incelenmiş, hatalar kategorize edilmiş fakat oransal açıdan hangi hata kaynağının ne kadar yapıldığı belirtilmemiştir. Yeo (2009) tarafından yapılan çalışmada ise sınırlı sayıda soru (3 soru) ve örneklem (56 öğrenci) üzerinde inceleme yapılmış, genelde yapılan hataların oranları belirtilmemiştir. Ülkemizde ise ilköğretim 5. sınıf öğrencilerinin rutin olmayan problemlerde yaptıkları hataların kaynağının belirlenmesine yönelik kapsamlı bir çalışmaya rastlanmamıştır. Gerek Fong (1995) ve Yeo (2009) tarafindan yapılan çalışmaların sınırlı olması ve gerekse ülkemizde böyle bir çalışmaya rastlanılmaması nedeniyle araştırmada ilköğretim öğrencilerinin rutin olmayan problemlerde yaptıkları hataların kaynağının belirlenmesinin gerektiği düşünülmüştür. Bu bağlamda araştırmada aşağıdaki sorulara cevap aranmıştır.

a) İlköğretim 5. sınıf öğrencilerinin rutin olmayan problemlerde yaptıkları yanlışların hata türleri bakımından dağılımları nasıldır?

b) İlköğretim 5. sınıf öğrencilerinin rutin olmayan problemlerde hata yapma nedenleri nelerdir?

\section{Yöntem}

\section{Araştırmanın Modeli}

Araştırmada betimsel tarama yöntemi ve klinik mülakat yöntemi beraber kullanılmıştır. 
Betimsel tarama modeli. Tarama modelleri, geçmişte ya da halen var olan bir durumu var olduğu şekliyle betimlemeyi amaçlayan araştırma yaklaşımlarıdır. Araştırmaya konu olan olay, birey ya da nesne, kendi koşulları içinde ve olduğu gibi tanımlanmaya çalışılır. Bilinmek istenen şey vardır ve oradadır. Önemli olan, onu uygun bir biçimde "gözleyip" belirleyebilmektir (Karasar, 2002). Bu bağlamda araştırmanın birinci problemi olan "İlköğretim 5. sınıf öğrencilerinin rutin olmayan problemlerde yaptıkları yanlışların hata türleri bakımından dağılımları nasıldır?” sorusunun cevabına araştırmacılar tarafından herhangi bir müdahale yapılmadığı için betimsel tarama modeli kullanılarak ulaşılmıştır.

Klinik mülakat yöntemi. Piaget "Çocukların yaptıkları hatalar, onların düşünce doğası ile ilgili önemli bilgiler verir, öğrencilerin düşüncelerindeki zenginliği keşfetmek ve bilişsel beceriyi değerlendirmek için esnek soru sorma metodu olan klinik mülakat yönteminin kullanılması gereklidir” görüşünü savunmaktadır (Akt: Baki ve Kartal, 2004). Frederiksen, Glaser, Lesgold ve Shafto (1990)'ya göre standart testlerin sadece öğrencinin ne kadar doğru veya ne kadar yanlış yaptığını ortaya çıkarabildiği, öğrencinin niçin yanlış yaptığını ve öğrencinin doğruya ulaşabilmesi neler yapılması gerektiğini sorgulamadığını belirtmişlerdir. Karataş ve Güven (2004) ise klinik mülakat yöntemini problem çözme becerisinin değerlendirilmesi için kullanılabilecek ölçme yöntemlerinden biri olarak görmekte, öğrencilerin problem çözerken yaptıkları hataların nedenlerinin ancak öğrencinin çözüm esnasında gözlemlenmesiyle ortaya çıkartılabileceği düşünmektedirler. Hunting (1997) ise klinik mülakat tekniğinin dinamik olduğunu ve daha çok öğrencinin yaptığı hataları kendisinin belirlediğini belirtmiştir. Araştırmanın ikinci problemi olan "İlköğretim 5. sınıf öğrencilerinin rutin olmayan problemlerde hata yapma nedenleri nelerdir?” sorusuna gerek öğrencilerin hata ve yanılgılarının altında yatan nedenleri ortaya çıkarmak ve gerekse öğrencilerin yaptıkları hataları kendilerinin belirleyebilmeleri ve farkına varabilmeleri için klinik mülakat yöntemi kullanılmıştır.

\section{Evren ve Örneklem}

Evren ve alt evrenler. Araştırmanın evrenini 2010-2011 öğretim y1lında Kütahya ili merkezinde bulunan 34 devlet okulunda öğrenim gören 5. sınıf öğrencileri oluşturmaktadır. $\mathrm{Bu}$ öğrencilerin tamamına ulaşmak zor olduğundan oranlı küme örnekleme yöntemi kullanılarak çalışma grubunun oluşturulmasına karar verilmiştir. Karasar (2002) evrendeki elemanların tek tek seçilme şansına sahip olmadıkları durumlarda küme örnekleme yöntemi kullanılarak çalışma grubunun seçilmesini önermektedir. Küme örnekleme yönteminde eşit seçilme şans1 elemanlar yerine, içindeki tüm elemanları ile birlikte kümelerindir. Oranlı küme örneklemede kümelerin seçiminde evren açısından önemli görülen bir değişken kategorize edilerek, bu değişkene göre evrendeki gruplar sınıflandırılarak alt evrenlere ayrılır. Alt evrenlerden küme seçimi yapılırken alt evrenin evren içindeki payı oranında küme seçilir. 
Oranlı küme örnekleme yapılırken araştırmanın evrenini oluşturan Kütahya merkezde bulunan 34 devlet okulunu alt evrenlere ayırabilmek için 2009 SBS ve 2010 SBS sınav sonuçları kriter alınmıştır. SBS sınavının ölçüt olarak kullanılması okulları başarı yönüyle kategorize edebilecek başka bir resmi kriterin bulunmamasıdır; 2009 ve 2010 SBS sonuçlarının kriter alınması ise okulların sadece bir yıllık başarı ortalamalarının yanıltma ihtimaline karşı alınmış bir tedbirdir. Bu bağlamda örneklemi oluşturabilmek amaciyla 34 devlet okulunun her birinin 2009 SBS ve 2010 SBS puan ortalamaları ((2009 SBS+2010 SBS)/2) hesaplanarak; okulların SBS başarı sıralamaları elde edilmiştir. Daha sonra Kütahya il merkezi 2009/2010 SBS ortalama ve standart sapma değerlerinden hareketle 34 okul alt evrenlere ayrılmıştır. Elde edilen bulgular Şekil 2'de verilmiştir.

Şekil 2. Araştırmanın Evrenini Oluşturan Kütahya İlinde Bulunan 34 Devlet Okulunun 2009/2010 SBS Sonuçlarına Göre Alt Evrenlere Ayrılması

265.99

294.51

323.03

\begin{tabular}{|l|l|l|l|}
\hline \multicolumn{1}{|c|}{ 4. alt evren } & \multicolumn{1}{|c|}{ 3. alt evren } & \multicolumn{1}{c|}{ 2. alt evren } & \multicolumn{1}{c|}{ 1. alt evren } \\
\hline Düzey: En düşük & Düzey: düşük & Düzey: Yüksek & Düzey: En yüksek \\
\hline Toplam: 5 okul (\%15) & Toplam: 14 okul (\%41) & Toplam: 9 okul (\%26) & Toplam: 6 okul (\%18) \\
\hline Örneklem: 1 okul & Örneklem: 3 okul & Örneklem: 2 okul & Örneklem: 1 okul \\
\hline
\end{tabular}

Ortalama $=294.51$

Standart Sapma $=28.52$

Şekil 2 incelendiğinde Kütahya ili 2009/2010 SBS ortalamasının 294,51; standart sapmasının 28,52 olduğu görülmüş, 34 okul alt evrenlere ayrılırken ortalama ve standart sapma değerleri ölçüt kabul edilmiştir. 2009/2010 SBS ortalamaları Kütahya ortalamasının üstünde olan okullar başarılı, altında olan okullar ise başarısız kabul edilmiştir. Başarılı okullardan $0,+1$ arasında standart puan alan okullar "yüksek", +1 'in üzerinde standart puan olan okullar ise "en yüksek" başarıya sahip okullar şeklinde sınıflandırılmıştır. Aynı sınıflama başarısız okullarda 0,-1 arasında standart puan alan okullar "düşük", -1'in altında standart puanı olan okullar ise "en düşük" başarıya sahip olan okullar şeklinde yapılmıştır. Bu sınıflamadan hareketle Kütahya il merkezinde bulunan 34 okul "en yüksek" başarıya sahip 6 okul (\%18), "yüksek" başarıya sahip 9 okul (\%26), "düşük" başarıya sahip 14 okul (\%41) ve "en düşük" başarıya sahip 5 okul (\%15) şeklinde alt evrenlere ayrılmıştır. Bundan sonraki aşamada alt evrenlere ayrılan 34 okuldan araştırmanın örneklemi seçilmiştir.

\section{Örneklem}

Şekil 2 incelendiğinde alt evrenlerde bulunan okulların geneli ortalamanın -1 ve +1 standart sapma bölgesinde toplandığı, +1 'in üzerinde ve -1 'in altında oransal açıdan 
daha az okulun bulunduğu görülecektir, örnekleme alınacak okullar seçilirken bu sistematiğe dikkat edilmiş, her bir alt evreni temsil eden okul sayısı, evrendeki okul sayılarına oranlanarak belirlenmiştir. Tablo 1'de araştırmanın çalışma grubunu oluşturan okullar, şubeler ve öğrenci sayıları verilmiştir.

Tablo 1

Çalışma Grubunu Oluşturan Okulların Başarı Düzeyi ve Seçilen Şubelerdeki Öğrencilerin Dă̆ılımı

\begin{tabular}{|c|c|c|c|c|c|c|}
\hline $\begin{array}{c}\text { Okul başarı } \\
\text { Düzeyi }\end{array}$ & Okullar & $\begin{array}{c}2009 / 2010 \\
\text { SBS } \\
\text { Ortalaması }\end{array}$ & $\begin{array}{c}\text { 2009/2010 SBS } \\
\text { Siralaması }\end{array}$ & Şube & $\mathbf{f}$ & $\%$ \\
\hline \multirow{2}{*}{ En yüksek } & \multirow[t]{2}{*}{ A Okulu } & \multirow[t]{2}{*}{339.86} & \multirow{2}{*}{3} & 1 & 37 & 7,9 \\
\hline & & & & 2 & 36 & 7,7 \\
\hline \multirow{4}{*}{ Yüksek } & \multirow{2}{*}{ B Okulu } & \multirow{2}{*}{322.15} & \multirow{2}{*}{7} & 1 & 34 & 7,3 \\
\hline & & & & 2 & 34 & 7,3 \\
\hline & \multirow{2}{*}{ C Okulu } & \multirow{2}{*}{312.64} & \multirow{2}{*}{12} & 1 & 37 & 7,9 \\
\hline & & & & 2 & 35 & 7,5 \\
\hline \multirow{6}{*}{ Düşük } & \multirow{2}{*}{ D Okulu } & \multirow{2}{*}{293.24} & \multirow{2}{*}{15} & 1 & 37 & 7,9 \\
\hline & & & & 2 & 40 & 8,6 \\
\hline & \multirow{2}{*}{ E Okulu } & \multirow{2}{*}{289.93} & \multirow{2}{*}{19} & 1 & 41 & 8,8 \\
\hline & & & & 2 & \multicolumn{2}{|c|}{ Çıkarıldı } \\
\hline & \multirow{2}{*}{ F Okulu } & \multirow{2}{*}{288.28} & \multirow[t]{2}{*}{22} & 1 & 36 & 7,7 \\
\hline & & & & 2 & 34 & 7,3 \\
\hline \multirow{2}{*}{ En düşük } & \multirow{2}{*}{ G Okulu } & \multirow{2}{*}{263.32} & \multirow{2}{*}{30} & 1 & 36 & 7,7 \\
\hline & & & & 2 & 30 & 6,4 \\
\hline
\end{tabular}

Tablo 1 incelendiğinde "en yüksek" başarı oranına sahip 6 okuldan 1, "yüksek" başarı oranına sahip 9 okuldan 2, "düşük" başarıya sahip 14 okuldan 3 ve "en düşük" başarı oranına sahip 5 okuldan 1 olmak üzere toplam 7 okul yansız atama yöntemiyle belirlenmiştir. Seçilen okullar Kütahya ili merkezinde bulanan okulların \% 20.58'ine tekabül etmektedir. Bu okulların 5. sınıf şube sayılarına bakılmış bazı okulların 5, bazı okulların 4, bazı okulların ise 3 şubesi olduğu görülmüş, şube sayılarının eşit olmaması nedeniyle 7 okulun her birinden 2 şube seçilerek çalışma grubu oluşturulmuştur. Şubeler seçilirken okul yöneticilerinden alınan bilgiler doğrultusunda okulun bulunduğu kategoriyi en iyi tanımlayan şubelerin seçimine özen gösterilmiştir. Örneğin "en yüksek" başarı düzeyine sahip 6 okuldan 1 tanesi yansız atama yöntemiyle seçilmiş ve bu okul "A Okulu" olmuştur. Bu okuldan 2 şube seçilirken okul "en yüksek" başarıya sahip okul kategorisinde bulunduğu için yönetici görüşleri doğrultusunda okuldaki 5 . sınıf şubeleri arasından en yüksek başarı düzeyine sahip 2 şube örnekleme dâhil edilmiştir. Örneklemde bulunan okulların isimleri ve 5. Sınıflarının şubeleri verilmemiş, bunun yerine 1 ve 2 kodları kullanılmış, E okulunun 2. şubesinde uygulama esnasında istenmeyen durumlara rastlandığından grubun tamamı ve bazı gruplarda bulunan 
kaynaştırma öğrencileri örneklemden çıkarılmıştır. Sonuç olarak 7 okul 13 şube ve 467 İlköğretim 5. sınıf öğrencisinden oluşan örnekleme ulaşılmıştır.

Klinik mülakat yöntemi için seçilen çalışma grubu ise çözümler incelendikten sonra farklı hataları yapan toplam 70 öğrenciden oluşturulmuş, yaptıkları hatalara göre bazı öğrencilerle sadece bir soru üzerinde bazı öğrencilerle yedi soruya varan görüşmeler yapılmıştır.

\section{Veri Toplama Araçları}

Rutin olmayan problem çözme başarı testi. Çalışmada ilköğretim öğrencilerinin rutin olmayan problemlerde yaptıkları hataları belirlemek amacıyla Ulu (2011) tarafından geçerlik ve güvenirlik çalışması yapılmış 12 sorudan oluşan rutin olmayan problem çözme başarı testi (ROPÇBT) kullanılmıştır. Karaca (2006), Tekin (1997) ve Yılmaz (1998)'a göre madde güçlük indeksi 0-1 arasında değişkenlik göstermekte olup, güçlük indeksleri 0.30-0.70 arasında olan maddeler ortalama güçlük düzeyindedir. ROPÇBT'de bulunan soruların madde güçlük indeksleri 0.33-0.58 arasında değişkenlik göstermekte olup bu bulgu testteki soruların tamamının orta güçlük düzeyine sahip olduğunu göstermektedir. Ayrıca testin ortalama güçlüğünün 0.38 olması da testin orta güçlükte olduğunu göstermektedir. Karaca (2006)'ya göre hata belirleme amaçlı kullanılan testler izleme testleri olup, bu testlerin orta güçlükte olması önerilmektedir. Bu nedenle hem testin bütününün hem de her bir sorunun orta güçlükte olması, soruların güçlük düzeylerinin testin amacına uygun olduğunu görmemizi sağlamıştır.

Bir testteki soruların kullanılabilmesi için sadece güçlük değerlerine bakmak yeterli değil aynı zamanda ayırt edici olmaları da gerekmektedir. Ayırt edicilik indeksi ise -1 ve +1 arasında değişmekte olup, bu değerin 0.40 ve üzerinde olması maddelerin ayırt edici olduklarını göstermektedir (Karaca, 2006; Tekin, 1997; Y1lmaz, 1998). Testte bulunan maddelerin ayırt edicilik indeksleri 0.45 ile 0.87 arasında değişkenlik göstermekte olup, bu bulgu maddelerin tamamının ayırt edici olduğunu göstermektedir. ROPÇBT'nin başarı testlerinde güvenirliğin ve iç tutarlılığın belirlenmesi amacıyla kullanılan KR-20 değerinin 0.91 olduğu görülmüştür. KR-20 değerinin 0.70 ve üzerinde olması testin iç tutarlılığın ve dolayısıyla güvenirliliğinin yüksek olduğunu göstermektedir (Büyüköztürk, 2006). Bu bulgudan hareketle testteki maddelerin iç tutarlılığının ve dolayısıyla testin güvenirliğinin yüksek olduğu sonucuna ulaşılmıştır. ROPÇBT Ek-1'de verilmiştir.

Klinik mülakat görüşme formu. Öğrencilerin rutin olmayan problemlerde niçin hata yaptıklarını belirlemek amacıyla Newman (1977) tarafından geliştirilen problem çözme hata analizi envanterinin White (2005) tarafından klinik mülakat görüşme formuna dönüştürülmüş hali kullanılmıştır. Klinik mülakat görüşme formu aşağıdaki sorulardan oluşmaktadır.

1. Problemde verilenler neler?

2. Problemde senden istenenler neler? 
3. Problemi çözmek için yaptı̆̆ın her bir işlemi neden kullandığını anlatır misin?

4. Sence sonuç doğru mu?

5. Doğru olmadığını düşünüyorsan nerede hata yapmış olabilirsin?

\section{Verilerin Toplanması ve Analiz Edilmesi}

ROPÇBT örneklem olarak belirlenen 13 sinıfta öğrenim gören toplam 467 ilköğretim 5. sınıf öğrencisine 45 dakika süre verilerek uygulanmış, uygulama esnasında öğrencilerin birbirinden etkilenmemesi için gereken tedbirler alınmıştır.

ROPÇBT'den elde edilen veriler analiz edilirken boş bırakılan sorular 0 , doğru yapılan sorular “1” ve yanlış yapılan sorular "2” şeklinde kodlanmış, 2 kodu verilen çözümlerin karşısına öğrencinin yaptığı yanlışın numarasını gösteren başka bir kod daha girilmiştir. Sürecin daha iyi anlaşılması açısından 1. soru üzerinde kodlamalar ve hata kaynaklarına nasıl ulaşıldığı gösterilmiştir. 1. soruda yapılan kodlamalar Tablo 2'de verilmiştir.

Tablo 2

Soru-1'in Analizinde Kullanılan Kodlar

\begin{tabular}{llc}
\hline Cevap & Cevap kodu & $\begin{array}{c}\text { Yanlış } \\
\text { kodu }\end{array}$ \\
\hline Boş & 0 & - \\
Doğru & 1 & - \\
Alakasız işlemler & 2 & 1 \\
Yağmurlu günde tarladan, güneşli günde asfalttan gidildiği düşünülmüşş & 2 & 2 \\
Gidiş dönüş güzergâhının yanlış belirlenmesi & 2 & 3 \\
Tatil günlerinde de okula gidildiği düşünülmüş & 2 & 4 \\
Sadece güneşli günlerde okula gidildiği düşünülmüş & 2 & 5 \\
Okula gidiş hesaplanmış ama dönüşler hesaplanmamış & 2 & 6 \\
\hline
\end{tabular}

Tablo 2 incelendiğinde 1. soru için 6 hata temasının olduğu görülecektir. Her bir hata teması için bir öğrenci belirlenerek klinik mülakatlar yapılmış, yapılan görüşmeler kamerayla kayıt altına alınmış ve raporlaştırılmıştır. Bu işlemler aynen 1. soruda olduğu gibi kalan 11 soru içinde yapılmış, belirlenen hata temaları çerçevesinde o hatayı yapan öğrencilerle klinik mülakatlar yapılmıştır. 12 soruda toplam 70 hata teması belirlenmiş; hata sayısına paralel 70 öğrenciyle klinik mülakat yapılmış ve raporlaştırılmıştır.

Raporlaştırma aşamasından sonra hataların kaynağı Yeo (2009) tarafindan problem çözme sürecinde verilen cevapları kategorize etmek amacıyla geliştirilen yedi aşamalı modele Fong (1995) tarafından öğrencilerin anlama kaynaklı hatalarını "ilgisiz işlem, hatalı tamamlanmamış ve hatasız tamamlanmamış" çözümler şeklinde kategorize 
eden model eklenerek belirlenmiştir. Rutin olmayan problem çözme hata analizi envanteri [Yeo (2009) tarafindan geliştirilen modele Fong (1995:18-20) anlama bölümündeki hata çeşitleri eklenmiş haliyle] ve hataların kategorize edilmesinde kullanılan kriterler Tablo 3'de verilmiştir.

\section{Tablo 3}

\section{Hataların Kategorize Edilmesinde Kullanılan Kriterler}

\section{Çözüm}

1. Boş

2. Okuma Hatas1

3. Anlama Hatas1

3.1. İlgisiz işlemler

3.2.Hatalı tamamlanmamış (Yanlış anlama)

3.3.Hatasız tamamlanmamış (eksik anlama)

4. Hatalı Strateji seçimi

5.Stratejinin Hatal1 yürütülmesi

6.İşlemlerin

Doğruluğu

7.Doğru Cevap

\section{Davranışlar}

Cevap kâğıdı üzerinde hiçbir işlem yapılmamışsa çözüm bu grupta değerlendirilmiştir.

Öğrencilerle yapılan klinik mülakatlarda öğrencinin bir kelimeyi yanlış okuduğu, bir kelime ve cümleyi okumadan atladığı belirlenirse yapılan hatanın okuma kaynaklı olduğuna karar verilmiştir.

Yapılan klinik mülakatlar sonucunda öğrencinin problem metninde verilenleri birbiriyle ilişkilendiremediği, problem metnindeki olay örgüsünün bir bölümünü yanlış veya eksik anlamlandırdığı görüldüğünde yapılan hatanın anlama kaynaklı olduğuna karar verilmiştir.

Çözümle yakında uzaktan ilgisi olmayan işlemler seçilmişse yapılan hatanın ilgisiz işlem seçiminden kaynaklandığına karar verilmiştir.

Öğrencilerin problem metnine bağlı çözüm yapmalarına rağmen, problem metnindeki olayların bir bölümünü yanlış yapılandırdıkları veya matematiksel ifadelere yanlış dönüştürdükleri görüldüğünde hatanın yanlış anlama kaynaklı olduğuna karar verilmiştir.

Öğrencilerin problem hikâyesindeki kronolojik sırayı takip ederek problemin bazı bölümlerini doğru yapılandırdıkları fakat problemin devamındaki olay akışını anlayamadıkları veya çözümün bittiğini düşündükleri için yarım bıraktıkları görüldüğünde hatanın eksik anlama kaynaklı olduğuna karar verilmiştir.

Yapılan görüşmelerde belirlenen stratejinin çözüme götürmeyeceği anlaşıldığında hata bu kategoride değerlendirilmiştir.

Yapılan görüşmelerde doğru strateji seçilmesine rağmen, stratejinin doğru yapılandırılamadığı görüldüğünde hata bu kategoride değerlendirilmiştir.

Doğru strateji seçilmesine ve yürütülmesine rağmen hesaplama hataları yapıldığında çözüm bu hata kategorisinde değerlendirilmiştir.

Yapılması gerekli bütün işlemler ve hesaplamalar doğru yapılmışsa çözüm doğru cevap kategorisinde değerlendirilmiştir.

Daha önceden raporlaştırılan 70 tema Tablo 3'te verilen kriterler doğrultusunda bir matematik öğretmenliği alan uzmanı ve sınıf öğretmenliği alan uzmanı tarafından incelenmiş, iki uzmanın ortak kanıları doğrultusunda baskın hata kaynaklarına göre kategorize edilmiştir. Tablo 2'yi tekrar incelediğimizde örnek sorumuz olan 1. soru incelendiğinde: 1. hata kodunda uzmanlar klinik mülakatlardan hareketle öğrencilerin problem metninden bağımsız rastgele çözümler yaptıklarını tespit etmişler, bu nedenle 
1. hata kodunun anlama eksikliğinden kaynaklandığını, anlama kaynaklı hatalardan da ilgisiz işlem kaynaklı hata olduğuna karar vermişlerdir. 2. hata kodu ise "Serkan'ın yağmurlu günlerde tarladan, güneşli günlerde asfalttan gitmesi gerektiğinin" düşünülmesidir; öğrencinin sorudaki "Serkan’ın yağmurlu günlerde asfalttan, güneşli günlerde tarladan gidip gelmektedir“ ifadesini anlamadığı görülmekte, bu nedenle 2 . hata kodunun anlama kaynaklı hatalı tamamlanmamış çözümler grubunda yer almasına karar verilmiştir. 3. hata kodunun ise "Serkan'ın gidiş dönüş güzergâhının yanlış belirlenmesi” olduğu görülecektir, soruda Serkan'ın yağmurlu günlerde asfalttan, güneşli günlerde tarladan gidip gelmektedir" ifadesi olmasına rağmen öğrencilerin bu ifadeyi doğru anlayamadıkları, "Serkan'ın aynı gün içerisinde asfalt yoldan okula gidip tarladan döndüğ̈̈nü " düşündükleri görülmüştür. Yapılan klinik mülakatlar neticesinde 3. hata kodunun da anlama kaynaklı hatalı tamamlanmamış çözümler grubunda yer almasına karar verilmiştir. 4. hata kodunda ise "Serkan sadece hafta içi okula gitmektedir. "ifadesi görülmemiş "Serkan'ın 7 gün okula gittiği" düşünülmüştür. Yapılan klinik mülakatlar neticesinde 4. hata kodunun da anlama kaynaklı hatalı tamamlanmamış çözümler grubunda yer almasına karar verilmiştir. 5. hata kodunda "Serkan o hafta hiç devamsızlık yapmamıştır" ifadesi bulunmasına rağmen bu hatayı yapan öğrenciler klinik mülakatlarda "Serkan ıslanacă̆ı için sadece güneşli günlerde okula gitmelidir” görüşünü savunmuşlardır. 5. hata kodunun olduğu çözümlerde hatalı işlem yapılmamasına rağmen çözümün yarıda bırakılması, hatanın anlama kaynaklı hatasız tamamlanmamış çözümler grubunda yer almasına neden olmuştur. 1. soruda 6. ve son hata kodu ise "Serkan'ın okula gittiğinin düşünülüp döndüğünün düşünülmemesidir” oysaki soruda "gidip gelmektedir” ifadesi yer almaktadır. Öğrencilerin bütün işlemleri eksiksiz yapmalarına rağmen sadece gittiği mesafeyi bulup dönüş mesafesini bulmamaları 6 . hata kodunun da anlama kaynaklı hatasız tamamlanmamış çözümler grubunda yer almasına neden olmuştur. Uzmanlar tarafindan her bir sorudaki hata kaynaklarının belirlenmesinden sonra hata kaynaklarının yapılma sıklığı belirlenmiştir. Hata kaynaklarının yapılma sıklığını belirlenmesinde yüzde (\%) ve frekans (f) analizi kullanılmıştır.

\section{Bulgular}

$\mathrm{Bu}$ bölümde araştırmanın problem cümleleri olan “İlköğretim 5. sınıf öğrencilerinin rutin olmayan problemlerde yaptıkları yanlışların hata türleri bakımından dağılımları nasıldır?" ve "İlköğretim 5. sınıf öğrencilerinin rutin olmayan problemlerde hata yapma nedenleri nelerdir?” sorularına cevap aranmış, elde edilen nicel bulgular Tablo 4'te verilmiştir.

\section{Boş Bırakılan Çözümler}

Tablo 4 incelendiğinde bütün sorularda \%27.6 (129) ile \%1.9 (8) arasında değişen oranlarda boş bırakılan çözümlerin olduğu görülecektir. Boş bırakılan çözümlerin testin geneline oranı ise \%14.96 (838)'dır. 


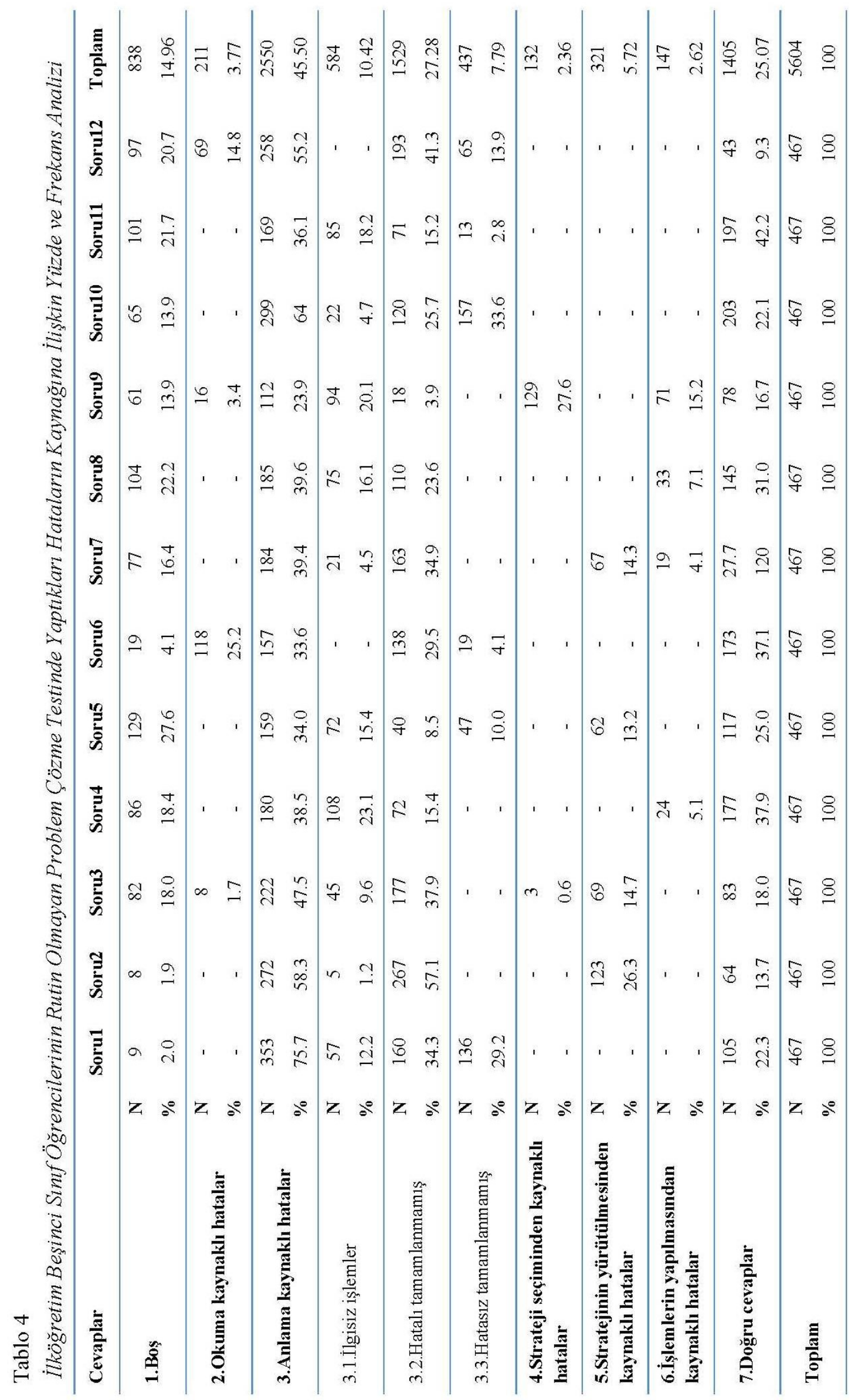




\section{Okuma Kaynaklı Hatalar}

Tablo 4 incelendiğinde okuma kaynaklı hataların toplam dört soruda (S3, S6, S9, S12 numaralı sorular) \%25.2 (118) ile \%1.7 (8) arasında değişen oranlarda yapıldığı, hataların testin geneline oranının ise \%3.77 (211) olduğu görülmektedir. Yapılan klinik mülakatlarda okuma kaynaklı hata yapan öğrencilerin aceleci davrandıkları için metnin bir bölümünü yanlış veya eksik okudukları görülmüştür. Yapılan incelemeler sonucunda yüksek başarı gösteren öğrencilerin düşük başarı gösteren öğrencilerden daha fazla bu hata türünü yaptıkları bulgusuna ulaşılmıştır. Okuma kaynaklı hataların en fazla yapıldığı 6. soruya ilişkin bir öğrencinin cevabı ve öğrenciyle yapılan mülakat Şekil 3'te verilmiştir.

Şekil 3. 6. Soruda Yapılan Okuma Kaynaklı Hata ve Öğrenci Görüşmesi

\begin{tabular}{|l|l|l|l|l|}
\hline & Tenis & Basketbol & Voleybol & Hentbol \\
\hline Ayşe & & & & \\
\hline Vildan & & & \\
\hline Caner & & & \\
\hline Derya & & & \\
\hline
\end{tabular}

M: zoruda zenden iaternen ne?

- Darada Ayse, Midan, Caner ve Derya dort arkadașhr. Eurfar farkh sporlar yepuyarlar. Her birinin

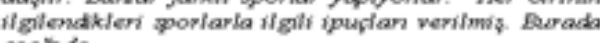
asagion.

M: Bvet ipuglan verdik.

O: Bir de burada bir fablo verilmis

M: Mesela Vildas in nedor volegbol oymati gra isaret. ledin.

O: Aurada hidan nolepbol oymamaktadir dipor. Ben

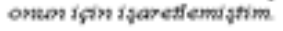

M. Ivef. Mesela Caner 5 neden baskefbol oynagor darak isareffedis?

O: Ben soyle yaphm. Caner ve Derya baskerbol omamaktadir diye ilk once Caner' isaretied m. Charka bas. kethol opmuarmas

M: Evet:

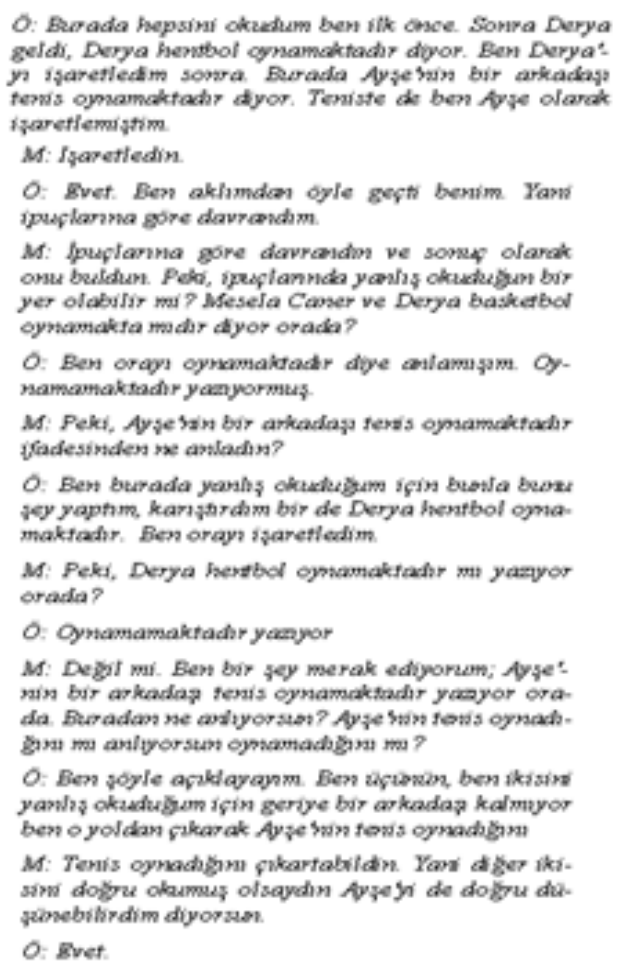

O: Berada hepsini okedum ben ilk once. Sanna Derya geldi, Derya hentbol oynamedtadir dyor. Ben Derya: yi isaretledim soowa. Berada Ayjeswin bir arkadays

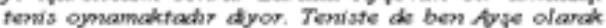
izoretiemistim.

M: Ssaretiedin.

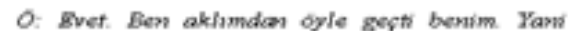
ipuplamana gore davrandim.

M: fpuplanna goine davrandin ve sones olanat

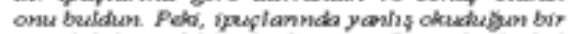
yer olabifir mi? Mesela Caser ve Derya baskefbol oymamakta madr dyor orada?

O. Ben oray oymamaktadr dipe calamsam. Oynamamaktadir yazyormus.

M. Peki, Ayse bain bir ankadas fersis omamaktadir jactesinden ye anladin?

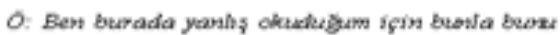
sey yoptum, kanjatadim bir de Derya hentbol omamaktiadir. Ben orayn isaretledim.

M: Pekt, Derya hertbol omamaktadir mo yazyor aradia?

O: Oymamamaktadis yacenor

M: Degit mi. Ben bir sey merak edjponam; Ayse'

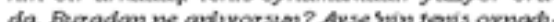

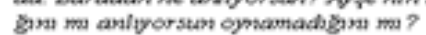

O- Ben soyle apldayaym. Ben açawan, ben ikising

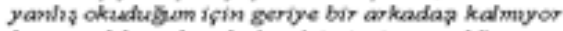
ben o yoldan gikearak Ayje swn fews oynadisgn

M: Tenis oynadhogn pikartabilidn. Yani di ger ikisim dolyu obumus ofraydin Apjeyi de do bu dusionebihndim diyorzan.

O: gvet.

\section{Anlama Kaynaklı Hatalar}

Tablo 4 incelendiğinde anlama kaynaklı hatalara \%75.7 (353) ile \%23.9 (112) arasında değişen oranlarda bütün sorularda rastlanmış olup, testin genelinde $\% 45.50$ (2550) en fazla yapılan hata türüdür. Anlama kaynaklı hatalar ilgisiz işlemler, hatalı tamamlanmamış (yanlış anlama), hatasız tamamlanmamış (eksik anlama) çözümler olmak üzere 3 kategoride incelenmiştir.

İlgisiz işlemler. İlgisiz işlem kaynaklı hatalara 6 ve 12. sorular hariç diğer bütün sorularda \%23.1 ile \%1.2 arasında değişen oranlarda rastlanılmış olup, bu hataların testin gelenine oranının \%10.42 (584) olduğu görülmüştür. Bu hatayı yapan öğrencilerin problem metnindeki ifadelerden bağımsız bir şekilde çözümle yakından uzaktan alakası 
olmayan işlemleri seçtikleri görülmüştür. İlgisiz işlem kaynaklı hataların en fazla yapıldığı 4. soruya ilişkin bir öğrencinin cevabı ve öğrenciyle yapılan mülakat Şekil 4'te verilmiştir.

Şekil 4. 4. Soruda Yapılan İlgisiz İşlem Kaynaklı Hata ve Öğrenci Görüşmesi
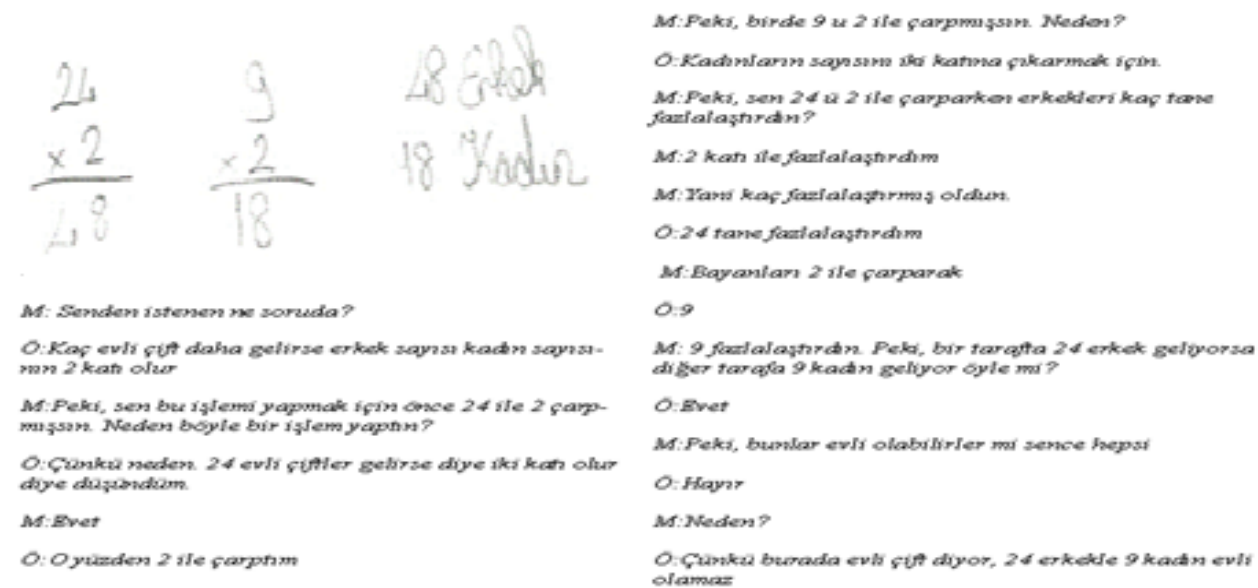

Hatalı tamamlanmamış (Yanlış anlama). Tablo 4 incelendiğinde hatalı tamamlanmamış çözümlere bütün sorularda \%57.1 (267) ile \%8.5 (40) arasında değișen oranlarda rastlanmış olup, bu hata türünün çalışmanın genelindeki yapılma oranı \%27.28 (1529)'dir. Hatalı tamamlanmamış çözümlerden en fazla yapıldığı 2. soruya ilişsin bir öğrencinin cevabı ve öğrenciyle yapılan mülakat Şekil 5 'te verilmiştir.

Şekil 5. İkinci Soruda Yapılan Hatalı Tamamlanmamış Çözüm ve Öğrenci Görüşmesi

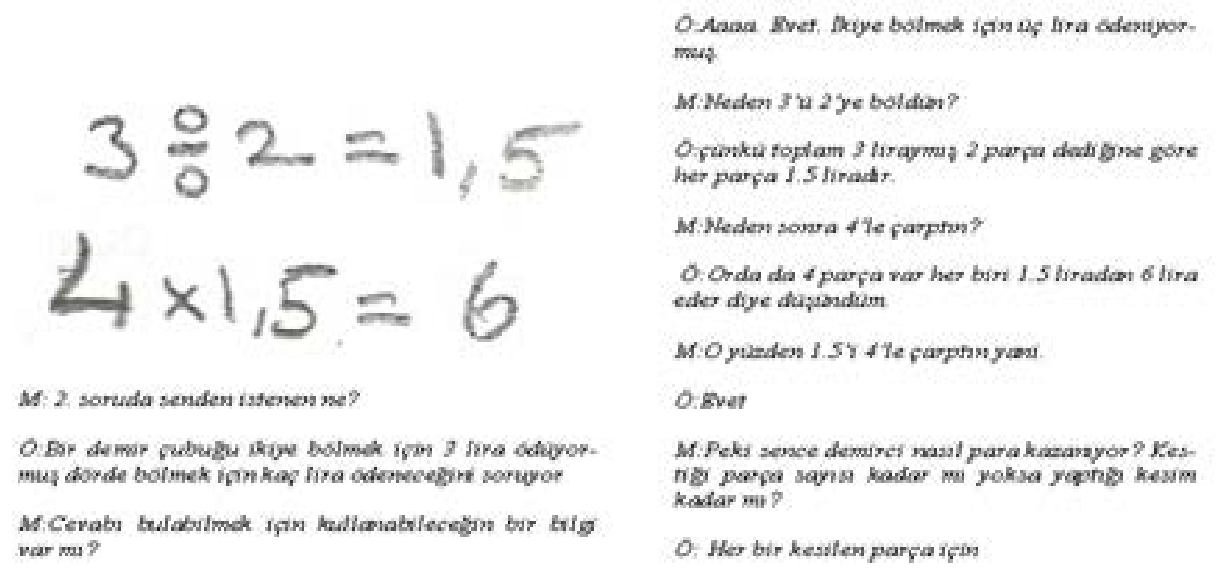

Hatalı tamamlanmamış çözümlerde öğrencinin sorunun bir bölümünü yanlış yapılandırdığı için sonucu yanlış bulduğu görülmektedir. Bu hatanın en fazla yapıldığı 2. soru incelendiğinde öğrenci bölünen parça adedi kadar para ödenmesi gerektiğini 
düşünmüştür, öğrenci parça için değil de kesim için ücret ödendiğini düşünseydi soruyu doğru yanıtlayacaktır.

Hatasız tamamlanmamış (Eksik anlama). Tablo 4 incelendiğinde hatasız tamamlanmamış çözümlere toplam 6 soruda (S1, S5, S6, S10, S11, S12 numaral1 sorularda) \%33.6 (267) ile \%2.8 (13) arasında değişen oranlarda rastlanmış olup, bu hata türünün çalışmanın genelindeki yapılma oranı \%7.79 (437)' dir. Bu hata türünde sonuca götüren işlemler doğru bir şekilde yapılandırılmış fakat yapılması gereken işlemlerden bir veya birkaçı eksik kalmıştır. Bu hatanın en fazla yapıldığı 10. soru incelendiğinde öğrenci çözüm için gerekli olan arkadaş sayısını bulmuş devamında Ali'nin arkadaşlarına verilen bilye sayısını da bulmuş fakat Ali'nin elinde olan bilyelere çözümünde yer vermemiştir; öğrenci bulduğu sonuca 12 olan Ali'nin bilyelerini dâhil etseydi doğru cevabı bulacaktı. Hatasız tamamlanmamış çözümlerden en fazla yapıldı̆̆ 10. soruya ilişkin bir öğrencinin cevabı ve öğrenciyle yapılan mülakat Şekil 6' da verilmiştir.

Şekil 6. 10. Soruda Yapılan Hatasız Tamamlanmamış Çözüm ve Öğrenci Görüşmesi

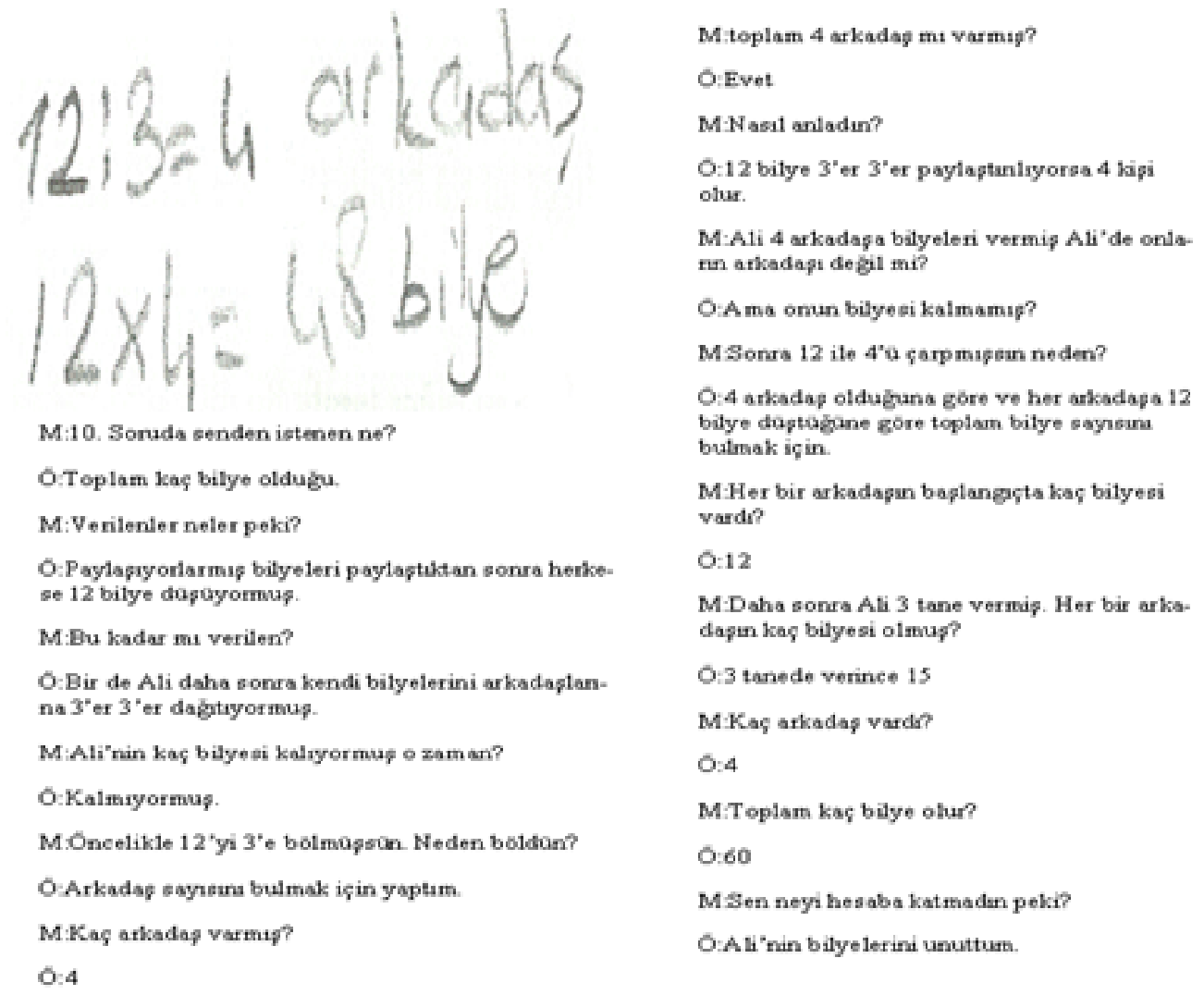

\section{Strateji Seçiminden Kaynaklı Hatalar}

Strateji seçiminden kaynaklı hatalarla toplam 2 soruda (S3 ve S9) \%27.6 (129) ile \%0.6 (3) rastlanmış olup, bu hata türünün genelde yapılma oranının \%2.36 (132) olduğu belirlenmiştir. Strateji seçiminden kaynaklı hataların en fazla yapıldığ 19 . Soru 
incelendiğinde öğrenciler soruda onları doğru çözüme ulaştıracak şekli çizmişler fakat bu stratejiyle çözüme gitmek yerine matematik cümlesi yazma stratejiyle çözüme gitmeyi tercih etmişlerdir. Matematik cümlesi yazma stratejisi eşitlik veya eşitsizliklerle çözüme gidilmesi şeklinde tanımlanmaktadır. Çözümde öğrenciler " 5 ev için 21 kibrit çöpü gerekirse 10 ev için 42 kibrit çöpüne ihtiyaç olur" şeklinde düşünerek oran/orantı kurmuşlardır. Oysaki ilk seçtikleri strateji olan şekil ve diyagram çizme stratejisinde 1srar ederek çözüme gitmeye çalışsalard1, çizdikleri şekildeki kibrit çöplerini saymaları bile doğru çözüme gitmelerini sağlayacaktı. Öğrencilerin 12 sorunun tamamında en fazla kullandıkları stratejinin matematik cümlesi yazma stratejisi olduğu görülmekte, bu durum ilköğretim öğrencilerinin çoğunluğunun problem çözme strateji bilgilerinin yetersiz olduğunu düşünmemize neden olmaktadır. Strateji seçiminden kaynaklı hataların en fazla yapıldığı 10. soruya ilişkin bir öğrencinin cevabı ve öğrenciyle yapılan mülakat Şekil 7'de verilmiştir.

Şekil 7. 9. Soruda Yapılan Strateji Seçiminden Kaynaklı Hatalı Çözüm ve Öğrenci Görüşmesi
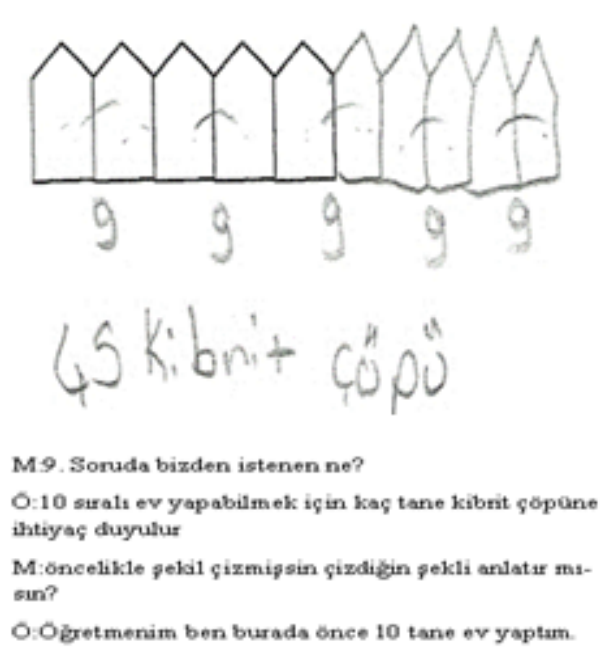

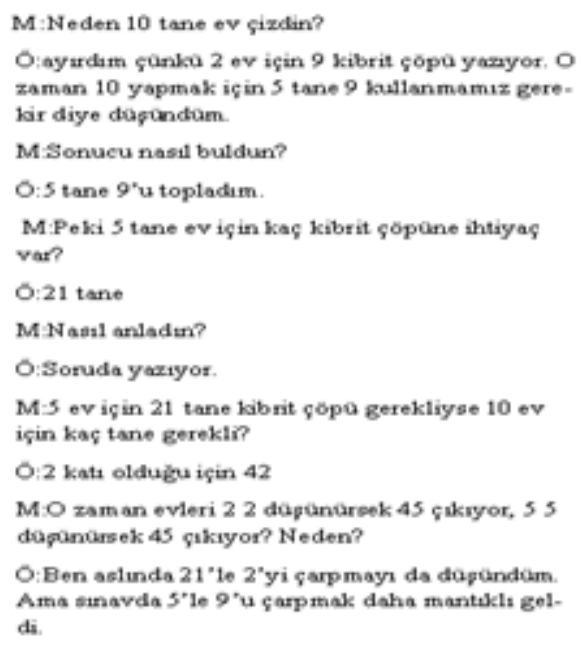

\section{Seçilen Stratejinin Yürütülmesinden Kaynaklı Hatalar}

Seçilen stratejinin yürütülmesinden kaynaklı hatalara4 soruda $(2,3,5,7$ numaralı sorular) \%26.3 (123) ile \%13.2 (62) değişen oranlarda rastlanmış olup, bu hata türünün genelde yapılma oranının \%5.72 (321) olduğu belirlenmiştir. $\mathrm{Bu}$ hata türünde öğrencilerin çözüme götürebilecek olan şekil ve diyagram stratejisini seçtikleri; doğru stratejiyi seçebilmelerine rağmen bazen şekli yanlış çizdikleri, bazende şekli doğru çizmelerine rağmen yanlış yorumladıkları görülmüştür. Stratejinin yürütülmesinden kaynaklı hataların en fazla yapıldığı 2. soruda öğrenci şekli 4 parçaya bölmesi gerekirken 3 parçaya bölmüş, 3 parça için 2 kesik atılması gerektiğini düşünerek 6 lira cevabına ulaşmıştır. Oysa öğrenci şeklinde yanlış yapılandırmayıp 4'e bölseydi doğru cevaba ulaşacaktı. Strateji yürütülmesinden kaynaklı hataların en fazla yapıldığı 2 . soruya ilişkin bir öğrencinin cevabı ve öğrenciyle yapılan mülakat Şekil 8'de verilmiştir. 
Şekil 8. 2. Soruda Yapılan Stratejinin Yürütülmesinden Kaynaklı Hatalı Çözüm ve Öğrenci Görüşmesi
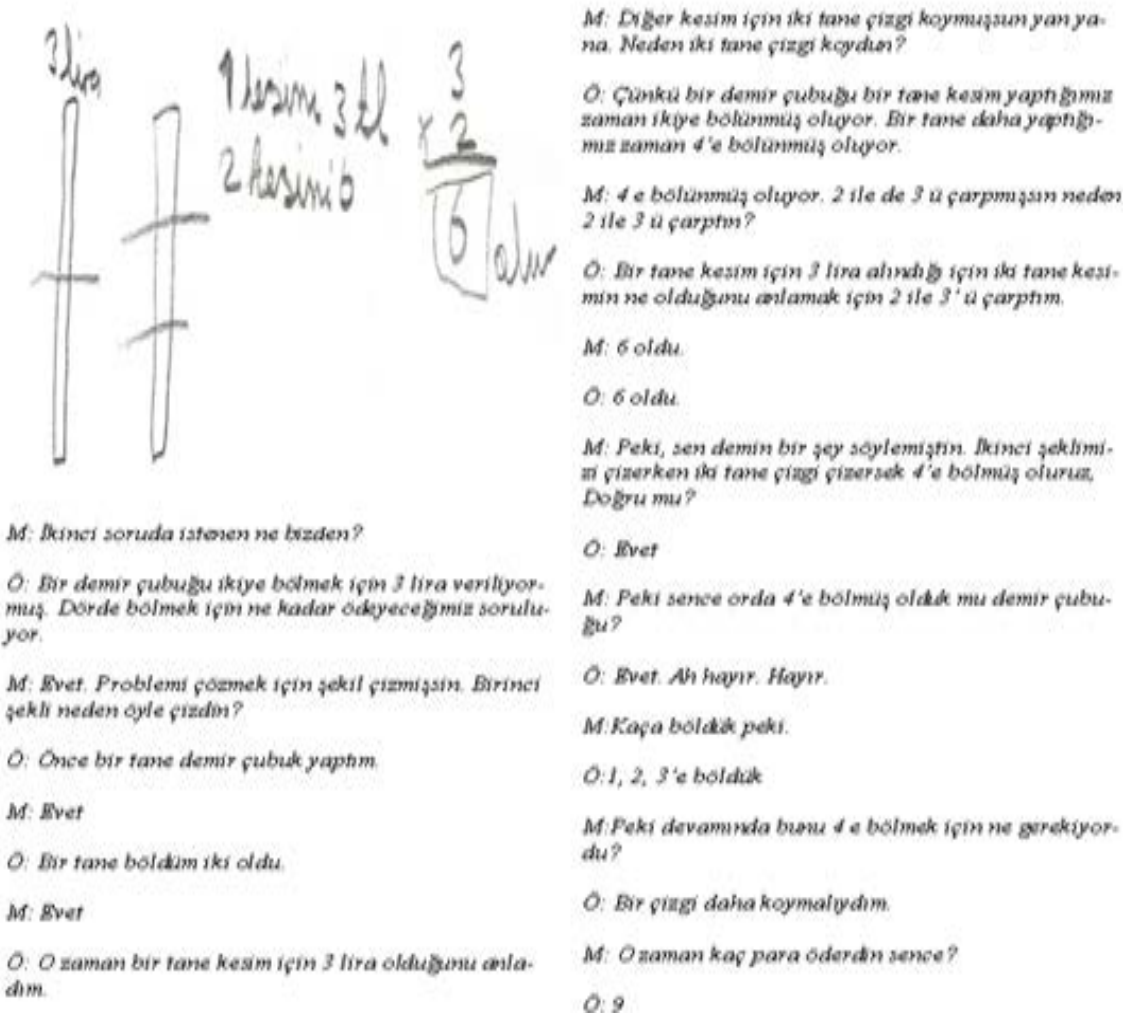

\section{İşlemlerin Yapılmasından Kaynaklı Hatalar}

İşlemlerin yapılmasından kaynaklı hatalara toplam 4 soruda (S4, S7, S8, S9 numaralı sorular) \%15.2 (71) ile \%4.1 (19) arasında değişen oranlarda rastlanmış olup, bu hata türünün genelde yapılma oranının \%2.62 (147) olduğu belirlenmiştir. Bu hata türünde öğrencilerin soruyu doğru anladıkları, doğru stratejiyi seçerek yürüttükleri fakat çözüme götüren işlemleri yanlış yaptıkları görülmüştür. İşlemlerin yapılmasından kaynaklı hataların en fazla yapıldığı 9. soruda öğrenciler şekil çizerek doğru stratejiyi seçmişler, teker teker kibrit çöplerini sayarak sonuca ulaşmaya çalışmışlar ancak hatalı saymışlardır. İşlemlerin yapılmasından kaynaklı hataların en fazla yapıldığı 9. soruya ilişkin bir öğrencinin cevabı ve öğrenciyle yapılan mülakat Șekil 9'da verilmiştir. 
Şekil 9. Dokuzuncu Soruda Yapılan İşlemlerin Yapılmasından Kaynaklı Hatalı Çözüm ve Öğrenci Görüşmesi

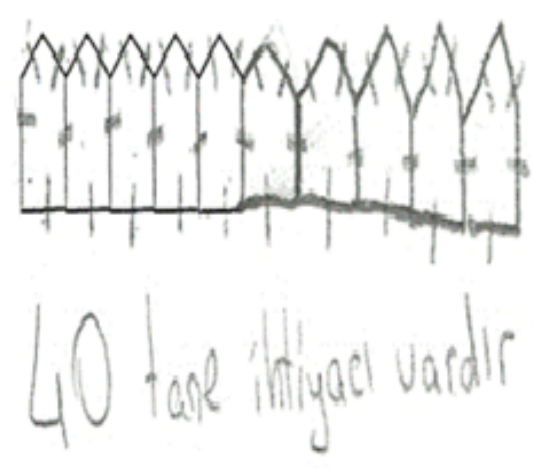

M: Senden istene ne 9. Soruda

0̈:9. Soruda dileğin yani... o sonuda ev yapabilmesi için kaç adet kibrit çöpüne intiyacı vardır diyor. M:Sen şekil çizmişsin.
Ö: Evet

M:Neden böyle bir şekil çizdin?

$\overline{0}: 10$ tane ev diye sorduğt için 10 tane ev yaptsm.

M.Sonta sonucu 40 bulmuşsun nasil buldun?

Ō:Sonra ögretmenim ben hepsini saydum 40 tane kibrit çöpüne ihtiyacs olduğunu görchür.

M:Peki bir de şimdi sayalım mi? Hadi say bakalim.

$0 \overline{:} 1.2 \ldots \ldots . .5,6.23,24, \ldots \ldots$. Yanlı̧̧ saydum. Pardon. $1,2,3, \ldots .16,17,18, \ldots 22, \ldots \ldots \ldots \ldots . . . .39$

MŞimdi 39 mu buldun?

0:Evet

Yapılan incelemeler sonucunda testin genelindeki yanlış oranları \%59.97 (3361)'dir; İlk iki hata türü okuma ve anlama kaynaklı olup bu hataların testin genelindeki çözümlere oranı \%49.26 (2761)'dır. Daha sonraki iki hata türü (strateji seçiminden ve stratejinin yürütülmesinden kaynaklı) ise problem çözme strateji bilgisi ile ilgili olup, bu hataların testin geneline oranı \%8.08 (453)'dir. Son hata türü ise işlemlerin yapılmasından kaynaklı olup, bu hata türünün testin geneline oranı $\% 2.62$ (147)'dir.

\section{Doğru Cevaplar}

Soruların doğru cevaplanma oranları ise \%37.9 (177) ile \%9.3 (43) arasında değişkenlik göstermekte olup, testin genelindeki doğru cevaplanma oranının \%25.07 (1405) olduğu görülmektedir.

\section{Sonuç ve Tartışma}

Çalışma sonucunda rutin olmayan problemlerde yapılan hataların yaklaşık \%75

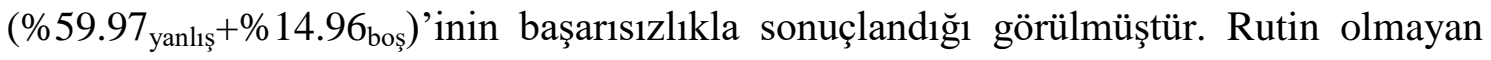
problemlerde yapılan hataların fazla olduğu bulgusu Verschaffel ve diğerleri (1994), Verschaffel ve diğerleri (1999), Jurdak (2006), Xin ve diğerleri (2007) tarafindan yapılan çalışmalarda elde edilen bulgularla uyuşmaktadır. Diğer taraftan Asman ve Markovits (2009) ve Ulu (2008) tarafından yapılan çalışmalarda rutin olmayan problemlerde öğretmenlerinde tıpkı öğrenciler gibi daha fazla hata yaptıkları ayrıca, Asman ve Markovits (2009) ile Lee ve Kim (2005) yaptıkları çalışmalarda rutin olmayan problemlerin öğretmenler tarafından derslerde kullanım oranlarının düşük olduğu bulgusuna ulaşmıştır. Araştırma sonucunda elde edilen rutin olmayan problemlerde başarının düşük olduğu bulgusu ülkemizdeki matematik ve sınıf 
öğretmenlerinin rutin olmayan problemleri derslerinde kullanıp kullanmadığının belirlenmesine yönelik çalışmalar yapılmasını gerekli kılmaktadır.

Araştırmadaki hata kaynakları incelendiğinde çözümlerin yaklaşık yarısının (\%49.26) okuduğunu anlama kaynaklı hataları barındırdığı görülmektedir. Araştırma sonucunda elde edilen öğrencilerin en fazla okuduğunu anlama kaynaklı hata yaptığı bulgusu Singh ve diğerleri (2010), Clements ve Ellerton (1996), Marinas ve Clements (1990), Clarkson (1991) tarafindan yapılan çalışmalarda elde edilen bulgularla uyuşmaktadır. İlköğretim öğrencilerinin problem çözme başarıları ile okuduğunu anlama becerileri arasında yüksek ilişki olduğu (Chinn ve Ashcroft,1993; Light \& DeFries, 1995; Grimm, 2008; Pape, 2004; Tuohimaa ve diğerleri, 2008) okuduğunu anlama becerisinin sınıf seviyesi arttıkça matematik öğretimini daha fazla etkilediği bulgusuna (Grimm, 2008) ulaşılmıştır. Ulu (2011) ve Hite (2009) tarafından yapılan çalışmalar ise sadece okuduğunu anlama eğitimi verilerek ilköğretim öğrencilerinin problem çözme başarılarının bir miktar artırılabildiğini göstermektedir. Bu çalışmada okuduğu anlama kaynaklı hataların fazla olması eğitim sistemimiz içinde problem çözme çalışmalarında okuduğunu anlamaya yönelik aktivitelerin artırılmasının ve okuduğunu anlama stratejilerinin problem çözme çalışmalarına uyarlanmasının gerekliliğini ortaya koymaktadır.

Çalışmada anlama kaynaklı hatalar ilgisiz işlemler, hatalı tamamlanmamış ve hatasız tamamlanmamış çözümler olmak üzere üç değişik biçimde kategorize edilmiştir. İlgisiz işlem kaynaklı olup, hatalara \%10.42 oranında rastlanılmış olup, bu yanlışı yapan öğrencilerin seçtikleri işlemlerin çözümle yakından uzaktan ilişkisi olmamasına rağmen yanlış seçtikleri işlemleri doğru yaptıkları belirlenmiştir. Benzer sonuçların Kroll ve Miller (1993), Tertemiz (1994), Prakitipong ve Nakamura (2006) tarafindan yapilan çalışmalarda da elde edilmesi; dört işlem problemlerinde yapılan hataların temel matematiksel becerilerden çok anlama kaynaklı olduğunu görmemizi sağlamıştır.

Çalışmada diğer anlama kaynaklı hataların problemdeki sözel ifadelerin görsel ve matematiksel ifadelere yanlış dönüştürülmesinden (hatalı tamamlanmamış çözümler \%27.28) veya eksik dönüştürülmesinden (hatasız tamamlanmamış \%7.79) kaynaklı olduğu görülecektir. Hegarty ve diğerleri (1995), Moreno ve Mayer (1999), Panasuk ve Beyranevand (2010) tarafindan yapılan çalışmalarda problemi anlamada çoklu dönüştürme" (sembolik, görsel, sözel) tekniklerini kullanabilen öğrencilerin daha başarılı oldukları sonucuna ulaşılmıştır. Bu araştırmada dönüştürme kaynaklı hataların fazla olması problem çözme etkinliklerinde çoklu dönüştürme tekniklerinin kullanılmasına önem verilmesi gerektiğini ortaya koymaktadır.

Problem çözme strateji bilgisinden kaynaklı hataların (strateji seçiminden ve stratejinin yürütülmesinden kaynaklı) testin geneline oranı \%8.08'dir. Problem çözme strateji bilgisinden kaynaklı hataların ilki stratejinin seçiminden kaynaklı hatalar olup bu hataların testin geneline oran1 \%2.36'dır. Schonfeld (2005) uygun stratejinin seçilebilmesi için öğrencilerin mümkün olduğunca farklı tipte problemlerle karşı karşıya getirilmesini önermektedir. Koedinger ve Tabahneck (1994) tarafindan yapilan çalışmada ise başlangıçta doğru strateji seçiminde bulunmayıp, aynı stratejide ısrar 
ederek çözüme giden bireylere oranla çıkmaza düştüklerinde kullandıkları stratejiyi değiştirerek tekrar çözüm yapan bireylerin daha başarılı oldukları görülmüştür. Ulu (2008) tarafindan yapılan çalışmada ilköğretim öğrencilerinin en fazla matematik cümlesi yazma stratejisini kullandığı belirlenmiş, benzer durum çalışmamızda da gözlemlenmiştir.

Problem çözme strateji bilgisinden kaynaklı hataların ikincisi stratejinin yürütülmesinden kaynaklı hatalar olup, bu hataların testin geneline oranı \%5.72'dir. Çalışmada bu hataların şeklin yanlış çizilmesinden veya doğru çizilmesine rağmen yanlış yorumlanmasından kaynaklandığı görülmüştür. Araştırma sonucunda elde edilen bu bulgu, Hong (1993/1995) ve Pantziara ve diğerleri (2009) tarafından yapılan çalışmalarda elde edilen bulgularla uyuşmaktadır.

Araştırma sonucunda bazı öğrencilerin yanlış strateji seçmeleri ve hep aynı stratejiyi (matematik cümlesi yazma stratejisi) kullanmaları, bazı öğrencilerinse seçtikleri stratejiyi yürütememeleri problem çözme strateji eğitimine ağırlık verilmesinin gerekliliğini ortaya koymaktadır. Nitekim Altun ve diğerleri (2004), Altun ve diğerleri (2004); Altun ve Arslan (2006), Sulak (2005), Yavuz (2006), Yazgan ve Bintaş (2005) problem çözme strateji eğitiminin problem çözme başarısı artırdığı görülmüştür.

Araştırmada işlemlerin yapılmasından kaynaklı hataların testin geneline oranının oldukça düşük (\%2.62) olduğu gözlemlenmiştir. Teong (2000) ve Özsoy (2007) tarafından yapılan çalışmalarda kontrol süreçlerinin kullanılmasının işlem kaynaklı hataları azalttı̆̆ı görülmüştür.

\section{Öneriler}

Çalışmada rutin olmayan problemlerde yapılan hataların oransal olarak fazla olması, bu hataların bir nebze olsun öğretmen kaynaklı olabileceğini düşündürmüştür. $\mathrm{Bu}$ bağlamda ülkemizde de öğretmenlerin rutin olmayan problemlere yönelik tutumları ve rutin olmayan problemleri matematik derslerinde kullanım oranlarını tespit etmeye yönelik çalışmalar yapılabilir.

Çalışma sonucunda rutin olmayan problemlerde yapılan hataların daha çok okuduğunu anlama kaynaklı olması, problemi çözmek için sadece matematiksel becerilerin yeterli olmadığını; bununla birlikte okuduğunu anlamaya yönelik dil becerilerinin de önemli olduğunu göstermektedir. Bu bağlamda Türkçe metinlerin çözümlenmesinde kullanılan okuduğunu anlama stratejileri problem çözme aktivitelerine uyarlanabilir.

$\mathrm{Bu}$ çalışma 4+4+4 eğitim sisteminden önce yapılması nedeniyle 5. sınıf öğrencilerinin matematik dersleri sınıf öğretmenleri tarafından yürütülmekteydi. Oysa 2012-2013 öğretim yılı itibariyle 5. sınıf matematik dersleri branş öğretmenleri tarafından yürütülmektedir. Bu durumun öğrencilerin problem çözme becerilerini ne düzeyde etkilediğini belirlemeye yönelik çalışmalar yapılabilir. 


\section{Kaynakça}

Akyol, H. (2006). Türkçe öğretim yöntemleri. Ankara: Kök Yayıncılık.

Altun, M. (2005). İlköğretimde matematik öğretimi. Bursa: Aktüel Alfa Bas. Yay.

Altun, M. (2007). Ortaöğretimde matematik öğretimi. Bursa: Aktüel Alfa Bas. Yay.

Altun, M., Bintaş, J., Yazgan, Y., \& Arslan, Ç. (2004). İlköğretim çă̆ındaki çocuklarda problem çözme gelişiminin incelenmesi. Uludağ Üniversitesi, Bilimsel Araştırma Projeleri Birimi, Bursa.

Altun, M. \& Arslan, Ç. (2006). İlköğretim öğrencilerinin problem çözme stratejilerini öğrenmeleri üzerine bir çalışma. Uludă̆ Üniversitesi Eğitim Fakültesi Dergisi, 19(1), 1-21.

Andersson, U. (2008). Mathematical competencies in children with different types of learning difficulties. Journal of Educational Psychology, 100(1), 48-66.

Anderson, U. (2010). Skill development in different components of arithmetic and basic cognitive functions: Findings from a 3-year longitudinal study of children with different types of learning difficulties. Journal of Educational Psychology, 102(1), 115-134.

Artzt, A. \& Armour-Thomas, E. (1992) Development of a cognitive - metacognitive framework for protocol analysis of mathematical problem solving in small groups. Cognition and Instruction 9(2), 137-175.

Asman, D. \& Markovits, Z. (2009). Elementary school teachers' knowledge and beliefs regarding non-routine problems..Asia Pacific Journal of Education, 29(2), 229249.

Baddeley, A. D. \& Logie, R. H. (1999). Working memory: The multiple-component model. In A. Miyake \& P. Shah (Eds.), Models of working memory (pp. 28-61). New York: Cambridge University Press.

Baki, A. ve Kartal, T. (2004). Kavramsal ve işlemsel bilgi bağlamında lise öğrencilerinin cebir bilgilerinin değerlendirilmesi. Türk Eğitim Bilimleri Dergisi, 2(1), 27-46.

Bautista, D., Mitchelmore, M., \& Mulligan, J. (2009). Factors influencing Filipino children's solutions to addition and subtraction word problems. Educational Psychology, 29(6), 729-745.

Büyüköztürk, Ş. (2006). Veri analizi el kitabı. Ankara: Pegem A Yayıncılık.

Charles, R. I. \& Lester, F. K. (1984). An evaluation of a process-oriented instructional program in mathematical problem solving in grades 5 and 7. Journal for Research in Mathematics Education, 15(1), 15-34.

Chinn, S. J. \& Ashcroft, J. R. (1993). Mathematics for dyslexics: A teaching handbook. London: Wiley-Blackwell.

Clarkson, P. C. (1991). Language comprehension errors: A further investigation. Mathematics Education Research Journal, 3(2), 24-33. 
Clements, M. A. (1982). Careless errors made by sixth-grade children on written mathematical tasks. Journal for Research in Mathematics Education, 13(2), 136144.

Clements, M. A. \& Ellerton, N. (1996). The Newman procedure for analyzing errors on written mathematical tasks. Retrieved August 17th, 2008 from http://users. tpg.com.au /arnold10/PAGES/newman.htm

Cummins, D. D., Kintsch, W., Reusser, K., \& Weimer, R. (1988). The role of understanding in solving word problems. Cognitive Psychology, 20(4), 405-438.

DeCorte, E. \& Verschaffel, L. (2002). High-powered learning communities: design experiments as a lever to bridge the theory/practice divide. Prospects: Quarterly Review of Comparative Education, 32, 517-531.

Duval, R. (2002). The cognitive analysis of problems of comprehension in the learning of mathematics. Mediterranean Journal for Research in Mathematics Education, 1(2), 1-16.

Fong, K. H. (1995). Schematic model for categorising children's errors in solving a ratio and proportion problem. Hiroshima Journal of Mathematics Education, 3, 15-29.

Frederiksen, N., Glaser, R., Lesgold, A., \& Shafto, M. (Eds.) (1990). Diagnostic monitoring of skill and knowledge acquisition. Mahwah, NJ: Lawrence Erlbaum.

Grimm, K. J. (2008). Longitudinal associations between reading and mathematics. Developmental Neuropsychology, 33(3), 410-426.

Gyamfi, A. K. (1993). External multiple representations in mathematics teaching (Unpublished master's thesis). Graduate Faculty of North Carolina State University.

Hallett, D., Nunes, T., \& Bryant, P. (2010). Individual differences in conceptual and procedural knowledge when learning fractions. Journal of Educational Psychology, 102(2), 395-406

Hanich, L. B., Jordan, N. C., Kaplan, D., \& Dick, J. (2001). Performance across different areas of mathematical cognition in children with learning difficulties. Journal of Educational Psychology, 93(3), 615-626.

Healy, L. \& Hoyles, C. (1999) Visual and symbolic reasoning in mathematics: Making connections with computers? Mathematical Thinking and Learning, 1(1), 59-84.

Hegarty, M., Mayer, R. E., \& Green, C. E. (1992). Comprehension of arithmetic word problems: Evidence from students' eye fixations. Journal of Educational Psychology, 84(1), 76-84.

Hegarty, M., Mayer, R. E., \& Monk, C. A. (1995). Comprehension of arithmetic word problems: A comparison of successful and unsuccessful problem solvers. Journal of Educational Psychology, 87(1), 18-32.

Hite, S. (2009). Improving problem solving by improving reading skills (Math in the Middle Institute Partnership Summative Projects for MA Degree). University of Nebraska - Lincoln. 
Hong, E. (1993). Mental models in word problem solving: An analysis of Korean elementary students. Paper presented at the Annual Meeting of the American Educational Research Association, Atlanta, GA.

Hong, E. (1995). Mental models in word problem solving: A comparison between American and Korean sixth-grade students. Applied Cognitive Psychology, 9(2), 123-142

Hunting, R. P. (1997). Clinical interview methods in mathematics education research and practice. Journal of Mathematical Behavior, 16(2), 145-165.

Jordan, N. C., Hanich, L. B., \& Kaplan, D. (2003). A longitudinal study of mathematical competencies in children with specific mathematics difficulties versus children with comorbid mathematics and reading difficulties. Child Development, 74(3), 834-850

Jordan, N. C., Kaplan, D., \& Hanich, L. B. (2002). Achievement growth in children with learning difficulties in mathematics: Findings of a two year longitudinal study. Journal of Educational Psychology, 94(3), 586-597.

Jurdak, M. (2006). Contrasting perspectives and performance of high school students on problem solving in real world situated, and school contexts. Educational Studies in Mathematics, 63(3), 283-301.

Karaca, E. (2006). Öğretimde planlama ve değerlendirme. Ankara: Nisan Kitabevi.

Karasar, N. (2002). Bilimsel araştırma yöntemleri. (2. basım) Ankara: Nobel Yayınevi

Karataş, İ. \& Güven, B. (2004). 8. Sınıf öğrencilerinin problem çözme becerilerinin belirlenmesi: Bir özel durum çalışması. Milli Eğitim Dergisi, 163, 132-143.

Kaur, B. (1997). Difficulties with problem solving in mathematics. The Mathematics Educator, 2(1), 93-112.

Kaur, B. \& Yeap, B. H. (2009). Mathematical problem solving in Singapore schools. In B. Kaur, B. H. Yeap, \& M. Kapur (Eds.), Mathematical problem solving: Yearbook 2009 (pp. 3-13). Singapore: Association of Mathematics Education and World Scientific.

Koedinger, R.K. \& Tabahneck, H.J.M. (1994). Two strategies are better than one: Multiply strategy use in word problem solving. Paper presented in annual meeting of the American educational research education, New Orleans, LA.

Kroll, D.L. \& Miller, T. (1993). Insights from research on mathematical problem solving in the middle grades. In D.T. Owens W. (Ed.), Research ideas for the classroom: Middle grades mathematics (pp.58-77). NY: Macmillan.

Lee, M. \& Kim, D. (2005). The effects of the collaborative representation supporting tool on problem-solving processes and outcomes in web-based collaborative problem-based learning (PBL) environments. Journal of Interactive Learning Research, 16, 273-293. 
Light, G. J. \& DeFries, J. C. (1995) Comorbidity of reading and mathematics disabilities: Genetic and environmental etiologies. Journal of Learning Disabilities, 28(2), 96-106.

Marinas, B., \& Clements, M. A. (1990). Understanding the problem: A prerequisite to problem solving in mathematics. Journal for Research in Science and Mathematics Education in Southeast Asia, 13(1), 14-20.

Marshall, L. (1995). Schemas in problem solving. NY: Cambridge University Press.

Mayer, R. E. (1985). Mathematical ability. In R. J. Sternberg (Ed.), Human abilities: An information processing approach (pp. 127-150). New York: Freeman.

Morales, R.V. (1998). Comprehension and solution patterns of simple math word problems by Mexican and American, bilingual, elementary school students. Paper presented at the Annual Meeting of the National Association for Bilingual Education. ED427544

Moreno, R. \& Mayer, R. E. (1999).Multimedia-supported metaphors for meaning making in mathematics. Cognition and Instruction, 17, 215-248.

Newman, M.A. (1977). An analysis of sixth-grade pupils' errors on written mathematical tasks. Research in Mathematical Education in Australia, 1, 239-258.

Özsoy, G. (2007). İlköğretim 5.Sınıfta problem çözme becerisi ile matematik başarışı arasındaki ilişki (Yayınlanmamış doktora tezi). Gazi Üniversitesi, Ankara.

Panasuk, R. M. \& Beyranevand, M. L. (2010). Algebra students' ability to recognize multiple representations and achievement. International Journal for Mathematics Teaching and Learning, 22, 1-22.

Pantziara, M., Gagatsis, A., \& Elia, I. (2009). Using diagrams as tools for the solution of non-routine mathematical problems. Educational Studies in Mathematics, 72(1), 39-60.

Pape, S. J. (2004). Middle school children's problem-solving behavior: A cognitive analysis from a reading comprehension perspective. Journal for Research in Mathematics Education, 35, 187-219.

Pape, S.T., \& Tchoshanov, M.A. (2001). The role of representations(s) in developing mathematical understanding. Theory Into Practice, 40(2), 118-127.

Passolunghi, M. C. \& Pazzaglia, F. (2004). Individual differences in memory updating in relation to arithmetic problem solving. Learning and Individual Differences, 14(4), 219-230.

Passolunghi, M. C. \& Pazzaglia, F. (2005). A comparison of updating processes in children good or poor in arithmetic word problem-solving. Learning and Individual Differences, 15(4), 257-269.

Polya, G. (1990). How to solve it? (Çev: Feryal Halatçı, 1997). New York.

Prakitipong, N., \& Nakamura, S. (2006). Analysis of mathematics performance of Grade 5 students in Thailand using Newman procedure. Journal of International Cooperation in Education, 9(1), 111-122. 
Schonfeld, A. H. (2005). Mathematics teaching and learning: A draft for the handbook of educational psychology (Second Edition). Berkeley, CA.

Singh. P, Rahman, A.A, \& Hoon, T.C. (2010). The Newman procedure for analyzing Primary four pupils errors on written mathematical tasks: A Malaysian perspective. Procedia Social and Behavioral Sciences, 8, 264-271

Singhatat, N. (1991). Analysis of mathematics errors of Iower secondary pupils in solving word problems. Penang: Seameo-Recsam.

Soylu, Y. \& Soylu, C. (2006). Matematik derslerinde başarıya giden yolda problem çözmenin rolü. İnönü Eğitim Fakültesi Dergisi, 7(11), 97-111.

Steele, D.F \& Johanning, D.I. (2004). A schematic-theoretic view of problem solving and development of algebraic thinking. Educational Studies in Mathematics,57, 6590.

Sternberg, R.J. (1988). Intelligence applied. Orlando, FL: Harcourt Brace Jovanovich.

Sulak, S. (2005). İlköğretim matematik dersinde problem çözme stratejilerinin problem çözme başarısına etkisi (Yayınlanmamış yüksek lisans tezi). Selçuk Üniversitesi, Konya.

Tekin, H. (1997). Ĕgitimde ölçme ve değerlendirme. Ankara: Mars Matbaası.

Teong, K. S. (2000). The effect of metacognitive training on the mathematical word problem solving of Singapore 11-12 year olds in a computer environment (Unpublished doctorate thesis). The University of Leeds, Leeds.

Teong, K. S. (2002). Metacognitive intervention strategy and word problem solving in a cognitive-apprenticeship-computer-based environment (Unpublished doctorate thesis). National Institute of Education, Nanyang Technological University.

Tertemiz, N. (1994). İlkokulda aritmetik problemlerini çözmede etkili görülen bazı faktörler (Yayımlanmamış doktora tezi). Hacettepe Üniversitesi, Ankara.

Tuohimaa, P.M.V, Aunola, B., \& Nurmi, J. (2008) The association between mathematical word problems and reading Comprehension. Educational Psychology, 28(4), 409-426

Ulu, M. (2008). Sinıf ögretmeni-sinıf ögretmeni adayı ve 5. Sinıf öğrencilerinin dört işlem problemlerini çözmede kullandıkları stratejilerin karşılaştırılması (Yayınlanmamış yüksek lisans tezi). Afyon Kocatepe Üniversitesi, Afyonkarahisar.

Ulu, M. (2011). İlköğretim 5. Sinıf öğrencilerinin rutin olmayan problemlerde yaptıkları hataların belirlenmesi ve giderilmesine yönelik bir uygulama. Gazi Üniversitesi, Yayınlanmamış Doktora tezi. Ankara.

Verschaffel, L. \& DeCorte, E. (1993). A decade of research on word-problem solving in Leuven: Theoretical, methodological and practical outcomes. Educational Psychology Review, 5, 239-256

Verschaffel, L., DeCorte, E., \& Lasure, S. (1994). Realistic considerations in mathematical modeling of school arithmetic word problems. Learning and Instruction, 4, 273-294. 
Verschaffel, L., DeCorte, E., \& Vierstraet, H. (1999). Upper elementary school pupils’ difficulties in modeling and solving non-standard additive word problems involving ordinal numbers. Journal for Research in Mathematics Education, 30(3), 265-285.

Viennot, D. C. \& Moreau, S. (2007). Arithmetic problems at school: When there is an apparent contradiction between the situation model and the problem model. British Journal of Educational Psychology, 77, 69-80

White, A. L. (2005). Active mathematics in classrooms: Finding out why children make mistakes - and then doing something to help them. Square One, 15(4), 127135

Wu, Z. \& King, J. (2011). Solving mathematical word problems in primary grades oral presentation. ICME 11- TSG24.1-8

Xin, Z., Lin, C., Zhang, L., \& Yan, R. (2007). The performance of Chinese primary school students on realistic arithmetic word problems. Educational Psychology in Practice, 23(2), 145-159.

Yavuz, G. (2006). Dokuzuncu sinıf matematik dersinde problem çözme stratejileri strateji öğretiminin duyuşsal özellikler ve erişiye etkisi (Yayınlanmış doktora tezi). Dokuz Eylül Üniversitesi, İzmir.

Yazgan, Y. \& Bintaş, J. (2005). İlköğretim dördüncü ve beşinci sınıf öğrencilerinin problem çözme stratejilerini kullanabilme düzeyleri: Bir öğretim deneyi. Hacettepe Üniversitesi Ĕ̈itim Fakültesi Dergisi, 28, 210-218.

Yeo, K. K. J. (2009). Secondary 2 students' difficulties in solving non-routine problems. International Journal for Mathematics Teaching and Learning, 8, 1-30.

Yılmaz, H. (1998). Eğitimde ölçme ve değerlendirme. (3. Baskı) Ankara: Mikro Yayınları. 


\section{Ek 1: Problemler}

1.Serkan yağmurlu günlerde okula asfalt yoldan, güneşli günlerde tarladan gidip gelmektedir. O hafta Pazartesi ve Çarşamba günleri yağmurludur. O hafta devamsızlık yapmayan Serkan kaç m yol yürümüştür? (Serkan sadece hafta içi okula gelmiştir.)

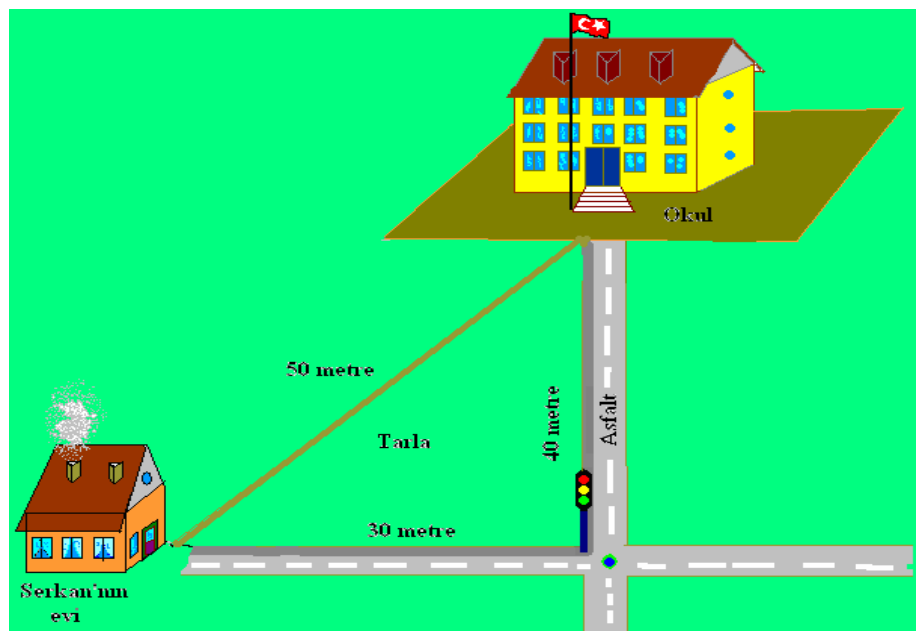

2. Bir demir çubuğu ikiye bölmek için 3 lira ödenmektedir. Bir demir çubuğu dörde bölmek için kaç lira ödenir?

3. Enes bir kitabı bir önceki gün okuduğunun 2 katını okuyarak 4 günde bitirmiştir. Enes'in okuduğu kitap 150 sayfadır. Enes birinci gün kaç sayfa kitap okumuştur?

4. Bir partide 24 erkek 9 kadın vardır. Kaç evli çift daha gelirse erkek sayısı kadın sayısının iki katı olur?

5. Bir balıkçı tuttuğu 5 balığı muz karşılığında manava veriyor.

1 balık 4 karpuz

1 karpuz 6 portakal

6 portakal 1 muz etmektedir. Balıkçı kaç muz alabilir?

6. Ayşe, Vildan, Caner ve Derya dört arkadaştır. Bu arkadaşlar tenis, basketbol, voleybol ve hentbol olmak üzere dört farklı sporla ilgilenmektedir. Her birinin ilgilendikleri sporla ilgili ipuçları aşağıdaki gibidir:

Ayşe'nin bir arkadaşı tenis oynamaktadır.

Caner ve Derya basketbol oynamamaktadir.

Derya hentbol oynamamaktadır.

Vildan voleybol oynamaktadir.

Yukarıdaki bilgilerden yola çıkarak her bir arkadaşın ilgilendiği spor türünü bulunuz?

\begin{tabular}{|l|l|l|l|l|}
\hline & Tenis & Basketbol & Voleybol & Hentbol \\
\hline Ayşe & & & & \\
\hline Vildan & & & & \\
\hline Caner & & & & \\
\hline Derya & & & & \\
\hline
\end{tabular}

7. Onur, Gökhan, Ezgi ve Çiğdem oyun parkına giderek tahterevalliye binmişlerdir.

Ezgi $30 \mathrm{~kg}$ olduğunu belirtmiştir.

Ezgi bir tarafa Çiğdem diğer tarafa bindiğinde tahterevalli dengededir. 
Onur bir tarafa, Ezgi ve Çiğdem diğer tarafa bindiğinde tahterevalli dengededir.

Onur bir tarafa Gökhan diğer tarafa bindiğinde, Onur aşağıdadır. Gökhan en fazla kaç kg'dır? (Cevap sayma sayısı olacak)

8. 700 öğrencisi olan bir okulun öğrenci sayısı her yıl 10 azalmaktadır. 580 öğrencisi olan bir okulun ise her yıl 5 artmaktadır. Kaç yıl sonra iki okulun öğrenci sayıları eşit olur?

9. Dilek kibrit çöpleriyle ev yapıyor. 2 ev yapmak için 9 adet kibrit çöpüne ihtiyacı vardır. 5 sıralı ev yapmak için 21 adet kibrit çöpüne ihtiyacı vardır. 10 sıralı ev yapabilmek için kaç adet kibrit çöpüne ihtiyacı vardır?

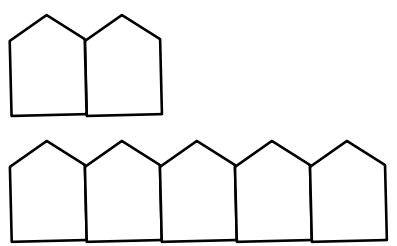

10. Ali bilyelerini arkadaşlarıyla eşit şekilde paylaştığında her kese 12 bilye düşüyor. Paylaştıktan sonra Ali her arkadaşına 3 bilye verirse bilyesi kalmıyor. Buna göre paylaşılan bilye sayısı kaçtır?

11. Usta ve iş̧̧ilerden oluşan 5 kişilik grup bir işten toplam 64 lira kazanmıştır. Bir usta 20 lira, bir işçi 8 lira almaktadır. Bu grupta kaç usta vardır?

12. Mustafa zayıflamak için spor yapmak istemektedir. Mustafa yüzme bilmemekte ve kolundaki sakatlık nedeniyle ağırlık çalışamamaktadır. Diğer sporlardan her birini en az 1 saat yapması gerekmektedir. Mustafa 4 saat çalışarak en fazla kaç gram verebilir? (Mustafa'nın kolundaki sakatlık sadece ağılık kaldırmasını engellemektedir.)

\begin{tabular}{|l|l|}
\hline Hareket & $\begin{array}{l}\text { 1 Saatte Verdiği } \\
\text { Gram }\end{array}$ \\
\hline Koşu Bandı & 400 \\
\hline Bisiklet & 600 \\
\hline Ağırlık & 700 \\
\hline Yüzme & 800 \\
\hline Minder Hareketleri & 500 \\
\hline
\end{tabular}

